\title{
ONREL
}
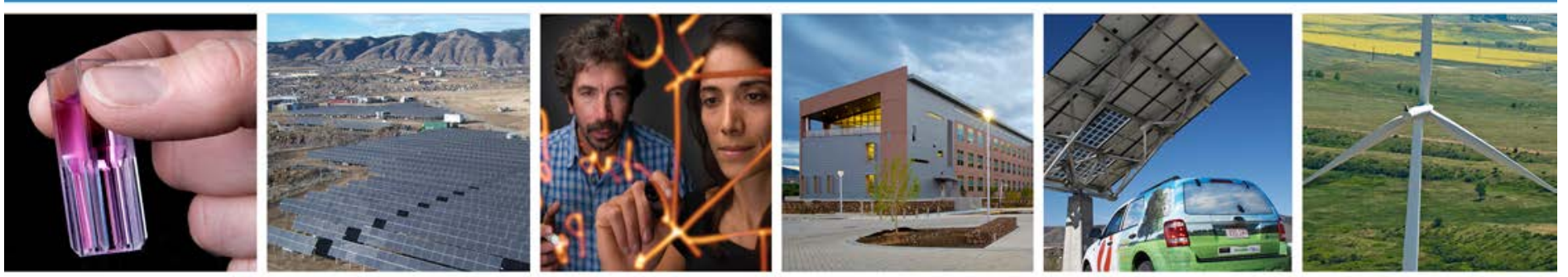

\section{Development of a Visual Inspection Data Collection Tool for Evaluation of Fielded PV Module Condition}

Corinne E. Packard National Center for Photovoltaics

National Renewable Energy Laboratory

Department of Metallurgical and Materials Engineering, Colorado School of Mines

John H. Wohlgemuth and Sarah R. Kurtz National Center for Photovoltaics

National Renewable Energy Laboratory

NREL is a national laboratory of the U.S. Department of Energy, Office of Energy Efficiency \& Renewable Energy, operated by the Alliance for Sustainable Energy, LLC.

Technical Report

NREL/TP-5200-56154

August 2012 


\title{
Development of a Visual Inspection Data Collection Tool for Evaluation of Fielded PV Module Condition
}

\author{
Corinne E. Packard
}

National Center for Photovoltaics

National Renewable Energy Laboratory

Department of Metallurgical and Materials

Engineering, Colorado School of Mines

John H. Wohlgemuth and Sarah R. Kurtz

National Center for Photovoltaics

National Renewable Energy Laboratory

Prepared under Task No. SS12.2560

National Renewable Energy Laboratory 15013 Denver West Parkway Golden, Colorado 80401 303-275-3000 • www.nrel.gov
NREL is a national laboratory of the U.S. Department of Energy, Office of Energy Efficiency \& Renewable Energy, operated by the Alliance for Sustainable Energy, LLC.

Technical Report

NREL/TP-5200-56154

August 2012

Contract No. DE-AC36-08G028308 


\section{NOTICE}

This report was prepared as an account of work sponsored by an agency of the United States government. Neither the United States government nor any agency thereof, nor any of their employees, makes any warranty, express or implied, or assumes any legal liability or responsibility for the accuracy, completeness, or usefulness of any information, apparatus, product, or process disclosed, or represents that its use would not infringe privately owned rights. Reference herein to any specific commercial product, process, or service by trade name, trademark, manufacturer, or otherwise does not necessarily constitute or imply its endorsement, recommendation, or favoring by the United States government or any agency thereof. The views and opinions of authors expressed herein do not necessarily state or reflect those of the United States government or any agency thereof.

Available electronically at http://www.osti.gov/bridge

Available for a processing fee to U.S. Department of Energy and its contractors, in paper, from:

U.S. Department of Energy

Office of Scientific and Technical Information

P.O. Box 62

Oak Ridge, TN 37831-0062

phone: 865.576 .8401

fax: 865.576 .5728

email: mailto:reports@adonis.osti.gov

Available for sale to the public, in paper, from:

U.S. Department of Commerce

National Technical Information Service

5285 Port Royal Road

Springfield, VA 22161

phone: 800.553 .6847

fax: 703.605.6900

email: orders@ntis.fedworld.gov

online ordering: http://www.ntis.gov/help/ordermethods.aspx

Cover Photos: (left to right) PIX 16416, PIX 17423, PIX 16560, PIX 17613, PIX 17436, PIX 17721

Printed on paper containing at least $50 \%$ wastepaper, including $10 \%$ post consumer waste. 


\section{Abstract}

A visual inspection data collection tool for the evaluation of fielded photovoltaic (PV) modules has been developed to facilitate describing the condition of PV modules with regard to field performance. The proposed data collection tool consists of 14 sections, each documenting the appearance or properties of a part of the module. This report instructs on how to use the collection tool and defines each attribute to ensure reliable and valid data collection. This tool has been evaluated through the inspection of over $60 \mathrm{PV}$ modules produced by more than 20 manufacturers and fielded at two different sites for varying periods of time. Aggregated data from such a single data collection tool has the potential to enable longitudinal studies of module condition over time, technology evolution, and field location for the enhancement of module reliability models.

\section{Keywords}

PV module, degradation, field data, materials

\section{Introduction and Overview}

Understanding how photovoltaic (PV) modules age is crucial for predicting lifetimes, particularly in varied climate zones that experience different environmental stressors. Achieving a climate zone-dependent reliability assessment requires a combination of weather models, accelerated testing results, and decades worth of field data. For new module designs and materials, however, a long history of performance in the field is not available. Even for existing materials and designs, data regarding observations of degradation are variable in detail, consistency, and statistical significance [1-5]. Here we attempt to regularize the collection of this data by developing a tool for the evaluation of visually observable defects in fielded PV modules. The key goal in this project is to deliver a data collection tool for the comprehensive evaluation of visual defects that appear over time in PV modules. This work supports the International Energy Agency Photovoltaic Power Systems (IEA PVPS) Programme's Task 13: Performance and Reliability of PV Systems, Subtask 3.2: Collecting Failures and Adapting Testing Methods to Failure Mechanism for PV Modules by providing a tool for the collection of consistent field data on module degradation and failure.

Based on the previous experience of our team, a draft data collection tool was developed, briefly tested on locally fielded modules, and then applied to a series of modules at Site 1 (the Sites are described in detail in Section 2 of this report). Following that site visit and discussions with participants on the IEA task force (listed in the Acknowledgements), modifications were made to the collection tool to improve comprehensiveness, clarity, and form usability. Data from modules from Site 2 were used to further improve the form, particularly the aspects pertaining to thin film modules, to generate the current version of the tool. In this report, the development of the collection tool is described, the types of visual defects are distinguished, and suggested analysis are presented.

In total, the data collection tool was developed through the evaluation of more than $60 \mathrm{PV}$ modules that represent a broad range of technologies, vintages, and field exposure times from three distinct field sites. The visual evaluation focuses largely on "symptoms" such as 
discoloration, haziness, and texture changes rather than "diagnoses" (e.g., hot-spots, electrochemical migration, etc.) to facilitate the collection of data for a larger number of modules than is feasible for in-depth laboratory studies, though these are recognized to be very important and may supplement the data collected with the tool. The collection tool consists of 14 sections based on module component, with inspection beginning at the rear side of the module, and then continuing on to the front. Every attempt was made to adhere to IEC/UL standard terminology. Additionally, we have attempted to balance the collection of sufficient detail for failure mode evaluation against desires to minimize recording time per module. Cataloging visually observable defects and correlating this data with electrical performance metrics will provide statistics that determine whether a particular visual defect is benign or will lead to efficiency loss. It is hoped that, by the large-scale collection of data from modules currently in the field around the world, lessons regarding material and system degradation may be accumulated and that this information can ultimately be used in the prediction of module lifetime and the development of improved PV modules.

\section{Description of Test Facilities}

Photovoltaic modules from 2 sites served as the principle testbeds for the development of the data collection tool, supplemented with the experience and knowledge of other professionals (identified in the Acknowledgements). Modules from Site 1 were inspected on location at the APS STAR Center (Arizona Public Services Solar Test and Research Center) in Tempe, Arizona USA. Modules from Site 2 were shipped from the field site at the Solar Energy Center (SEC) in New Delhi, India [6] to NREL for evaluation.
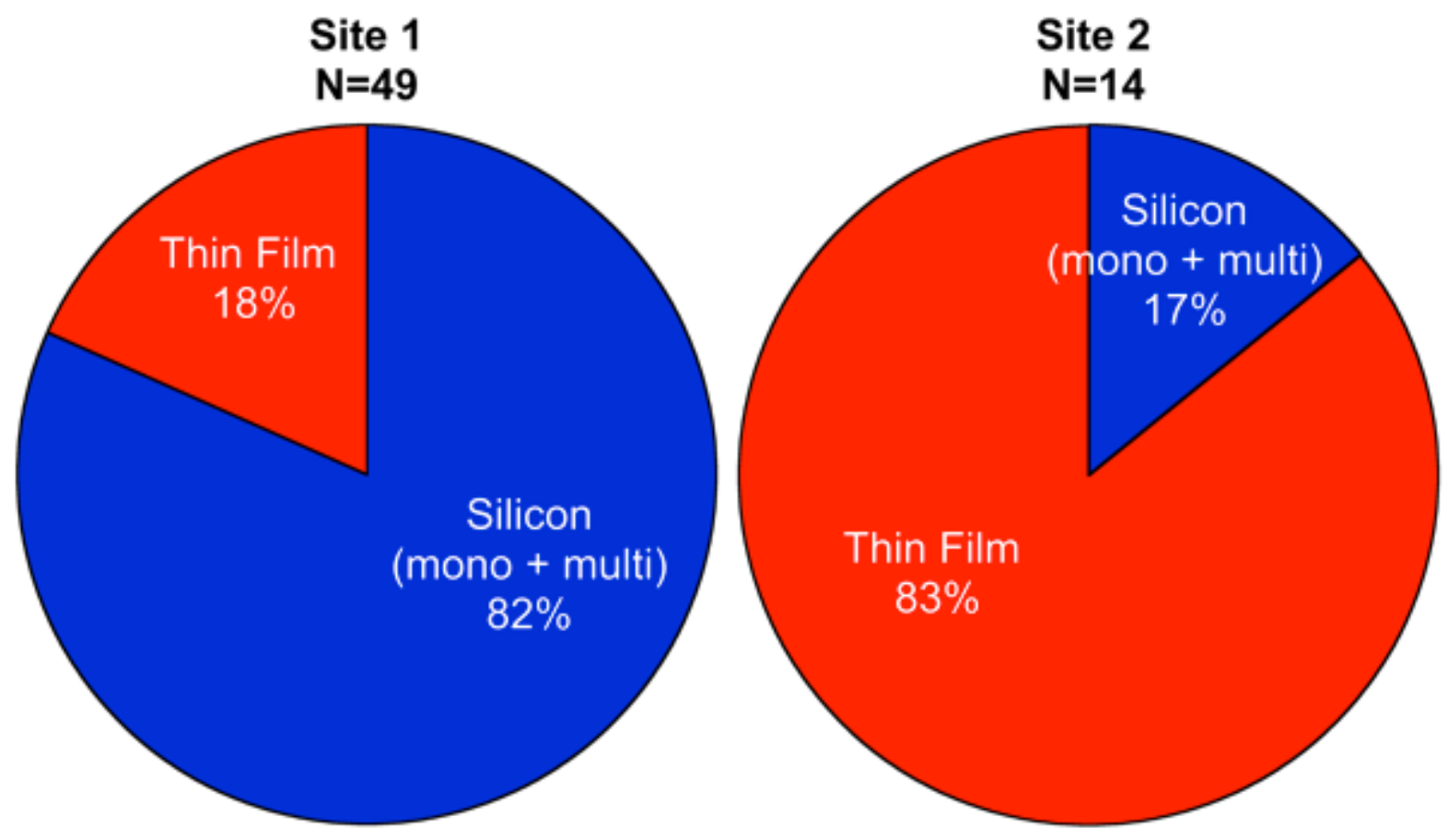

Figure 1. Composition of module sets at Site 1 and Site 2 used for early testing of the data collection tool. 
In all, 49 modules from Site 1 and 14 modules from Site 2 were inspected, representing 20 and 7 different manufacturers, respectively. The composition of the sets of modules from the two sites varied significantly. As can be seen in Figure 1, the majority of modules from Site 1 were crystalline silicon (either monocrystalline or polycrystalline), while the majority of modules derived from Site 2 were based on thin film technologies. In addition to covering a broad range of technologies and manufacturers, these modules experienced different exposure times in the field: modules were fielded between 1 and 12+ years at Site 1 and 1 and 10 years at Site 2 [6]. Modules from Site 2 were unmounted at the time of inspection, while modules from Site 1 were mounted on open racks that permitted inspection from both the front and the back.

\section{Visual Inspection Data Collection Tool}

A long form data collection tool is composed of 14 sections and is included in the Appendix A1 of this report. A short form data collection tool is also presented for use in certain situations. This short form is discussed in Section 4 of this report. With regard to the long form, Sections 1-3 collect information about the field site, system configuration, and module identification. Sections 4-13 focus on individual module components, starting from the back and ending at the front of the module. Section 14 documents locations of electronic records (I-V curves, infrared images, etc.). A complementary presentation providing photographic examples of many defects is found in the Appendix (A2). In the sections that follow, detailed instructions are given for each part of the collection tool to reduce ambiguity and variation in survey responses. If a new type of defect is found that cannot be adequately described by the options available in the tool, a section title "Other" is available for recording anomalous observations at the end of the collection tool. For data collection requiring numerical input (e.g., altitude, length), metric units are assumed throughout the collection tool. In order to complete the inspection, the following tools are required: a tape measure with centimeter and millimeter gradations, a pen or other recording implement, and any personal protective equipment required by the facility. A digital camera is recommended. If electronic records will be taken, the following equipment is recommended: an I-V curve tracer, and an infrared camera. In the data collection tool's current form, it takes a pair of two experienced inspectors approximately 8 minutes to conduct a full visual evaluation of a single module. This process could be significantly streamlined for data sets consisting of a large number of similar modules, since several entire sections could be filled out in advance and/or removed from the active inspection. We estimate that a set of modules with the same model number and from the same manufacturer could be visually evaluated by two experienced individuals in a period of $4-5$ minutes per module.

\subsection{Site Information}

The first section of the collection tool records data regarding the date, location, and the module inspector. The Location field should include the site name (where applicable), city, state or province, and country. The Latitude and Longitude fields should be recorded to the nearest hundredth of a degree and should indicate the direction from the equator ( + for North, - for South) or from the Prime Meridian (+ for East, - for West). For example, the location of NREL would be recorded as Latitude: +39.74 , Longitude: -105.18 . Altitude should be recorded to the nearest meter. 


\subsection{System Data}

Section 1 focuses on collecting relevant data for the design of the PV system. For systems in which multiple modules are wired together in an array, details contained in the "Multiple module system" sub-section will provide the level of information needed to differentiate defects that occur only under certain system conditions that may not occur in single module researchtype installations (i.e., only in a module at the end of a string). Under System bias, one of five options should be selected: open circuit, resistive load (for situations where a constant resistive load is applied), maximum power tracked, short circuit, or unknown (for systems where the bias condition is not known or has been varied among different configurations throughout the history of the installation). The System grounding should be recorded as "grounded," "not grounded," or unknown (for systems where the grounding condition is not known or has been varied among different configurations throughout the history of installation). It should be noted that this section does not refer to the module frame grounding, which is handled in Section 7. For grounded systems, indicate whether the system is grounded on the positive side, negative side, or center of the string. If the module is not wired as part of a multiple module system, "single module" should be selected under System design, and the questions regarding system bias and grounding should be answered based on how the individual module is biased and grounded.

\subsection{Module Data}

First, the module technology type should be recorded by selecting one of the following options: mono Si (for modules made up of single crystal silicon wafers), multi Si (for modules made using polycrystalline silicon cells), a-Si (amorphous silicon), CdTe (cadmium telluride), CIGS/CIS (copper indium gallium selenide/copper indium selenide), or other. If "other" is selected, the technology type should be entered into the provided blank space, avoiding proprietary technology names. Following recording of the system data and module technology type, the inspection begins at the rear side of the module. Any certifications listed on the module nameplate (also referred to as the label) should be indicated by checking one or more options listed in the Certification section and/or listing any other certifications in the space provided. If the nameplate does not indicate any IEC, UL, or other certifications, this category should be recorded as "unknown." The estimated deployment date should be recorded as the nearest known date or date range in which installation occurred. If electronic records will be collected from multiple modules, we have found it prudent to take a photo of the module nameplate at this point in the inspection to mark the start of the photo set for the particular module at hand. Information indicated on the nameplate regarding manufacturer name, model number, and module serial number should be recorded in the spaces provided. If the installation site or facility marks each module with a serial number internal to the site, space is provided for recording this information, which may be left blank otherwise. The width and length of the module, measured to the outside edge of the module frame, should be recorded to the nearest centimeter. For modules that are rectangular in shape, the width is considered to be the shorter of the two measured dimensions, regardless of module installation orientation. The electrical performance characteristics listed on the module nameplate should be recorded under the Nameplate section, where $\mathrm{P}_{\max }$ is the maximum power, $\mathrm{V}_{\mathrm{OC}}$ is the open circuit voltage, $\mathrm{I}_{\mathrm{sc}}$ is the short circuit current, Sys Volt is the rated system voltage, $\mathrm{V}_{\max }$ is the maximum voltage, $\mathrm{I}_{\max }$ is the maximum current, $\mathrm{I}_{\mathrm{f}}$ is the fuse current rating for the bypass diode, and Series fuse corresponds to the current rating for the series fuse. If any of the previously listed specifications are not indicated on the nameplate, the corresponding space(s) should be left blank. 


\subsection{Rear-Side Glass}

Section 3 corresponds to the evaluation of glass on the backside of the module. If the module construction simply has a backsheet and no rear-side glass, the section should be marked as "not applicable" and the inspector should proceed to Section 4. For modules with rear-side glass, the extent of damage should be evaluated. If the rear-side glass is in like-new condition, "no damage" should be marked and the inspector should proceed to Section 4. For modules with some type of damage, the damage should be categorized as "small, localized" if the damage is restricted to isolated areas totaling less than $10 \%$ of glass area, while damage that affects substantial area (>10\% of area) and/or appears to be associated with module failure should be marked as "extensive." For modules that exhibit either small, localized damage or extensive damage, the inspector should mark all applicable damage types, consisting of "crazing or other non-crack damage," "shattered (tempered)," "shattered (non-tempered)," "cracked," and "chipped." Differentiating between tempered or non-tempered glass is accomplished by observing the size and shape of the shattered glass fragments; glass that has been tempered exhibits many small fragments, whereas non-tempered glass tends towards larger, sharp shards. For modules that have cracked or chipped, further information regarding the number of cracks/chips and their locations should be cataloged by filling in the additional information in (a.) for cracked modules and (b.) for chipped modules. Regarding cracking, it has been observed that cracks may occur due to features intrinsic to a module design or its behavior in the field (hot spots, etc.) or due to extrinsic occurrences such as impact by hail, rocks, or other foreign bodies. As such, the inspector is asked to provide the location of the crack origin by choosing among the options: module corner, module edge, cell, junction box, and foreign body impact location.

\subsection{Backsheet}

Section 4 describes the backsheet in modules that exhibit this type of construction. If the module does not have a backsheet (for example, a module with rear-side glass instead), the section should be marked as "not applicable" and the inspector should proceed to Section 5. Modules having a backsheet are evaluated based on their appearance, texture, material quality, and evidence of damage. The backsheet generally consists of a white plastic sheet or laminate that covers the back of the module. The appearance of the backsheet should be categorized as "like new," "minor discoloration," or "major discoloration." Discoloration that is considered minor refers to an observed color that is most easily described as a tone of the original color (for example, a backsheet that was originally white shows off-white or yellowish-white coloring), while major discoloration is reserved for cases where the discolored area is better described as a different color (e.g., yellow, brown, or black). Given options for evaluating the defects in the texture of the backsheet include the following: like new, wavy (not delaminated), wavy (delaminated), and dented. "Wavy (delaminated)" should be selected for cases where bumps, bubbles, or ripples in the backsheet have an air gap between the backsheet and the rest of the module or between layers of a multilayered backsheet. The Material quality section is evaluated by passing a finger across the backsheet. Evidence of white powder transfer to the finger indicates a chalking quality which should be categorized as either "slight" or "substantial," depending on the amount transferred.

As in Section 3, the inspector is asked to evaluate Damage to the backsheet by indicating the types of damage present and providing additional detail for each according to the correspondingly lettered follow-up questions. The fraction of area exhibiting a particular damage type should be estimated by eye to the closest available option among $<5 \%, 5-25 \%, 50 \%$, or $75-$ 
$100 \%$ (consistent overall). Photographs of damage to module backsheets including burn marks, bubbles, and delamination can be found in Slides 6 and 7 of A2.

\subsection{Wires/Connectors}

Section 5 pertains to the wires protruding from the junction box and the connectors on those wires. If there are no wires and/or there are no connectors, the corresponding section should be marked as "not applicable" and the inspector should proceed to Section 6. For modules that have wires, their coating should first be evaluated as "like new," "pliable, but degraded," or "embrittled" by light, manual manipulation. If the wires exhibit damage, such as cracked/disintegrated insulation, burn marks, corrosion, or animal bites/marks, all types of damage present should be marked. The condition of the connectors should also be cataloged, as well as connector type and any observed damage. Photographs of damaged wires and connectors and common connector types are found in Slides 8 and 9 of A2.

\subsection{Junction Box}

Section 6 focuses more closely on the junction box itself. For modules where the junction box is incorporated inside the frame of the module, the inspector should mark the section as "not applicable/observable" and proceed to the next section. The physical state of the junction box is evaluated first. If the component is damaged in a way that alters its shape or is in a state that manipulation would be expected to result in fragmentation, the physical state should be marked as "unsound structure." The damage to the junction box should be further classified by selecting all applicable damage types among the following options: weathered, cracked, burnt, and/or warped. "Weathered" refers to damage due to environmental exposure such as UV damage, abrasion, or leaching and is manifested as a color or texture change. The condition of the junction box lid is to be classified as "intact/potted" (intended for undamaged lids and for junction boxes that are encapsulated or filled with silicone sealant or other potting compound during manufacture), "loose," "fell off" (if it is no longer present), or "cracked."

Following inspection of the junction box itself, the inspector should direct attention to the adhesive that secures the junction box to the back of the module. For modules in which a bead of adhesive is visibly protruding from underneath the junction box, the inspector should mark "applicable" and should evaluate the attachment of the junction box and the adhesive pliability by light, manual manipulation. For a module where the junction box's adhesive is not visible (for instance, it may be attached by double-sided tape that does not protrude), "not applicable/observable" should be marked and the inspector should advance to the evaluation of the junction box wire attachments. For modules with attached wires, the inspector should evaluate how well attached the wires are to the junction box, the quality of the seal between the wires and the junction box (if there is no seal or the seal is compromised in a way which would allow liquid water to flow into the junction box, "seal will leak" should be chosen), and whether there is evidence of prior arcing.

\subsection{Frame Grounding}

Section 7 evaluates the presence and condition of frame grounding. If the module design is frameless or the module frame is non-conductive, check "not applicable" and move to the next section. For module designs that lack a proper frame grounding clip or connection and/or for modules that have such a fixture, but has not been connected, the inspector should mark the Original state as "no ground." Wired or resistive grounds should be marked accordingly. 
"Unknown" is provided as an option for situations where the frame grounding has been varied over time or is unknown, as is common in cases where the modules have been taken from the field site for evaluation elsewhere. Evaluation of the Appearance provides the options of "not applicable" (for cases where no frame grounding mechanism is evident), "like new," "some corrosion," or "major corrosion." Finally, the Function of the frame grounding is visually evaluated as "well grounded" or "no connection."

\subsection{Frame}

Beginning with Section 8, the inspection is conducted on the front side of the module. For glassglass laminate modules that do not have a frame, "not applicable" should be selected and the inspector should proceed to Section 9. In inspecting the Appearance of the frame, the inspector should choose one option from among "like new," "damaged," or "missing." Any evidence of damage including minor corrosion, major corrosion, frame joint separation, frame cracking, a bent frame, and/or discoloration should be recorded by selecting as many options as apply. Evidence of discoloration or corrosion may occur due to the damage to an anodization layer either during manufacture, shipping, installation, or use. A frame joint separation of $>0.25 \mathrm{~mm}$ has been suggested as a threshold separation distance for classification as a defect [7]. Often a bead of adhesive is applied between the top surface of the module and the frame. For manufacturing purposes, it has been suggested that a proper adhesive application should be smooth, consistent, and uniform with a height of not less than $1 \mathrm{~mm}$ and not more than $6 \mathrm{~mm}$ [7]. The inspector should evaluate the presence and uniformity of this adhesive if it is visible.

\subsection{Frameless Edge Seal}

Frameless modules may employ an edge seal, which is the subject of inspection in Section 9. An edge seal is a seam of polymeric material that is intended to create a moisture barrier between plates of glass. It is usually white or gray in color and is not to be confused with a bead of silicone sometimes placed between plates of glass in frameless modules (Examples of each are shown on Slide 13 of A2). The inspector should evaluate the appearance of the edge seal, giving further information about the fraction of area affected if the material is discolored. All applicable damage types should be selected, with the fraction of area affected indicated if delamination has occurred. Photographs of damaged edge seals are provided on Slide 14 of A2.

\subsection{Glass/Polymer (Front)}

Section 10 focuses on the condition of the front panel of the module. The front panel material should be chosen from among the following options: glass, polymer, glass/polymer composite, or unknown. The features of the front panel, such as whether it is smooth (has a flat surface with no intended texture), slightly textured (raised features $<<1 \mathrm{~mm}$ in size), has a pyramid/wave texture (textured features $\sim 1 \mathrm{~mm}$ in size), and/or has an antireflection coating, should be noted. The Appearance field documents the presence, location, and degree of soiling on the glass. Soiling refers to any foreign matter deposited on the front panel or degradation caused by sedimentation of rainwater, ion leaching, or ion exchange, and is more prevalent in framed modules [2]. Oftentimes, the composition of soiling consists of an assortment of soot particles, soluble salts, and fine and coarse deposited particles, the composition of which is discussed in detail in Ref. [8]. For the purposes of this data collection tool, the module is inspected in its present condition without washing. As such, we do not differentiate between soiling that may be removed by washing and that which is well adhered to the surface. "Lightly soiled" is 
differentiated from "heavily soiled" by the likelihood of influencing light transmittance, where "heavily soiled" is expected to significantly obscure transmittance in the area which is affected.

Damage to the front panel should be classified as to its degree ("no damage," "small, localized," or "extensive") and the type of damage present. For further detail on differentiating between degrees of damage and identifying damage types, the inspector should refer to the guidance provided in Section 3.3 of this report. Photographs of damage and soiling are available on Slides 17 and 18 of A2.

\subsection{Metallization}

Section 11 covers the inspection of cell metallization and electrical interconnect within a module. For the purposes of this collection tool, we have adopted the following definitions with regard to individual metallization and interconnect components, comprising up to four levels of metallization:

1. Gridlines/Fingers- finest level of metallization, $<1 \mathrm{~mm}$ wide

2. Busbars- connect gridlines/fingers within a single cell; often obscured by cell interconnect ribbon

3. Cell Interconnect Ribbon- connects multiple cells into a string

4. String Interconnect- connects multiple strings of cells

A schematic distinguishing these components is presented on Slide 17 of A2. All four levels of metallization may not be utilized, depending on the module configuration (particularly for thin film modules). If any given level of metallization (as defined above) is not present or is not observable (e.g., busbars are obscured by overlapping cell interconnect ribbon, string interconnect is covered by module frame, etc.), the inspector should mark the corresponding section as "not applicable/not observable." For metallization that can be visually inspected, the inspector should evaluate its appearance and any damage. If a particular metallization component shows discoloration, the fraction of metallization area that is affected should be estimated to the nearest category $(<5 \%, 5-25 \%, 50 \%, 75-100 \%$ (consistent overall)). "Light discoloration" is taken to mean an apparent luster loss or yellowing of the metallization, while "dark discoloration" is reserved for metallization that is brown or black in color. Corrosion is marked by the presence of galvanic products that may appear powdery, white, light gray, and/or have a yellow, blue, or green tinge. Burn marks are often indicated by the presence of brown or black coloration, bubbling or melting of the polymeric encapsulant, and/or glass breakage or local loss of backsheet material (c.f. damage caused by hot-spots in resistive solder bonds in Ref. [5]). Slides 18 and 19 of A2 illustrate some of these conditions.

\subsection{Silicon (Mono or Multi) Module}

Section 12 pertains to single and polycrystalline silicon modules. Amorphous silicon and other thin film modules should not be evaluated under this section, thus "not applicable" should be marked and the inspector should proceed to Section 13. For modules where this section is applicable, the inspector should first record the total number of cells in the module, the number of cells composing each string, and the number of strings wired in parallel. The cell size should be measure to the nearest tenth of a centimeter. The minimum distance between the frame and 
the closest cell, as well as the closest distance between cells in a string, should be recorded using the options available on the data collection tool.

Following inspection of the layout, Discoloration is evaluated. Discoloration mainly refers to the darkening and loss in transparency of the encapsulant on top of silicon PV cells [9-13]. Firstly, the inspector should classify the predominant discoloration as "none/like new," "light discoloration," or "dark discoloration." Here, "light discoloration" is intended to represent the development of yellowing or haze, while "dark discoloration" is reserved for orange or brown shades. The inspector should record pertinent details about the number of discolored cells, degree of discoloration, and all locations where discoloration is present. The area above the junction box should be evaluated separately, and compared with any predominant discoloration over the rest of the module, as increase temperature in this area may enhance existing or generate new degradation mechanisms [2]. Slides 20-22 in A2 illustrate several different common and rare discoloration patterns.

The presence of Damage and Delamination are evaluated in successive sections. In both cases, all damage types that are present and delamination locations should be noted, and additional detail should be provided if the defect has a lettered cross-reference for further evaluation. Additional information regarding delamination in silicon modules and worm marks (interchangeably called snail tracks) can be found in Refs. [2] and [14], respectively. Many photographic examples are provided on Slides 23 and 24 of A2, which illustrate specific types of defects.

\subsection{Thin Film Module}

Section 13 pertains to thin film modules including amorphous silicon, CdTe, CIGS/CIS, and emerging technologies that are more similar to these than crystalline silicon wafer technologies. It is expected that either Section 12 or Section 13 will be completed in full, but not both. If this section is applicable to the module under inspection, the inspector should first describe the module layout by providing the total number of cells (with each cell defined by adjacent scribe lines, generally resulting in $>30$ cells per module), the number of cells per string, and the number of strings wired in parallel, if applicable. Cell size should be estimated to the nearest tenth of a centimeter, with the width and length considered to be the short and long directions, respectively. The minimum distance between the frame and cells edges should be categorized as less than or greater than $10 \mathrm{~mm}$.

Following evaluation of the module layout, the Appearance is inspected. Subtle changes from the original color or appearance or changes over $<10 \%$ of the module area should be noted as "minor/light discoloration," while gross changes to the appearance or color or that cover $>10 \%$ of the module should be marked as "major/dark discoloration." If any discoloration is observed, the inspector should provide additional information regarding discoloration type and location, marking all applicable options. Damage to the module is then evaluated, using similar definitions for the extent of damage as used throughout the collection tool. Any applicable damage types should be selected from among the list: "burn mark(s)," "cracking," "possible moisture" (for cases where there is evidence of corrosion or moisture ingress or the potential for moisture ingress), and "foreign particle embedded" (which refers to a manufacturing defect that occurs during the lamination process, but is cataloged in case its presence precipitates additional defects). Lastly, the module should be inspected for evidence of Delamination. The extent of 
delamination should be categorized as "no delamination," "small, localized," or "extensive." Any locations where delamination has occurred should be noted, as well as the predominant delamination type, which can be categorized as "absorber delamination," "AR coating delamination," or "other." Absorber delamination is marked by a silver or sparkling appearance that often begins from module edges and follows along the edges of scribe lines to create a characteristic appearance referred to as 'bar-graph'-type delamination $[15,16]$, whereas AR coating delamination has the appearance of bubbles or buckling [17]. Photographs of modules demonstrating an assortment of defects are shown in Slides 25 and 26 of A2.

\subsection{Electronic Records}

Section 14 provides a space to record various electronic records. If no electronic records are taken, "not applicable" should be marked and the rest of the section should be bypassed. Spaces are provided to provide the filenames for electronic records of digital photo files, I-V curve(s) [18], and electroluminescence (EL) and infrared (IR) images. Space is also provided for recording the measured irradiance and temperature and the sensors used for their respective measurements. If I-V response is measured, the inspector should evaluate the connector function as one of the provided options: functions, no longer mates, or exposed (connector does not properly seal the electrical connection). The inspector may also choose to perform a test of the bypass diodes. If this test is performed, the total number of diodes should be recorded, along with the number of diodes that are found to be shorted or in open circuit condition, and any evidence of damage or overheating of diodes.

\section{Short Form Data Collection Tool}

Though a detailed knowledge of module condition is often necessary to diagnose the cause of degradation or failure, it may not be practical to collect all of the detailed data requested in A1. In cases where large numbers of modules must be processed quickly (PV recyclers, warrantee return, and field inspection of grid-scale installations, for example), collecting a subset of data can still provide meaningful, yet less comprehensive, statistics for failure analysis purposes. In A3, we have provided a short form collection tool. This tool follows the same structure and format as the long form collection tool in A1, while removing much of the detail about damage location and quantification of damage extent. As a result, select data fields from A1 and A3 can be merged for analyses.

\section{Data Analysis}

Since the purpose of this project was to develop a standardized inspection data collection tool for visually observable defects in fielded PV modules that could be related to module degradation and failure, analysis of the data collected is premature. Regardless, suggestions can be made on how to conduct such future analyses pertaining to climate-zone dependent degradation, frequency of defect appearance over time for a given set of modules, or the specific influence of certain defect types on electrical performance. Such preliminary analysis of the data collected from Sites 1 and 2 are enumerated below in Table 1. As the data collection tool was being improved at the time of data collection, there were differences in the tool itself and the instructions given to inspectors for evaluation of modules from the two sites. As such, the data are presented separately, rather than in aggregate. Differences in commonly observed defects between the sites may be partially attributable to (1) differences in data collection procedure (as 
described above), (2) variations in age and composition of the modules between the sites (c.f. Fig. 1. For example, encapsulant discoloration is a common defect in the Site 1 modules, which are predominantly mono- or multi-crystalline silicon, whereas this defect does not appear in the list most frequently observed defects for Site 2, composed of mainly thin film modules), and/or (3) differences in environmental stressors in the two locations. Large-scale data collection, aggregation, and detailed analysis are needed to distinguish these effects.

Table 1. Top Five Most Commonly Observed Defects in Module Sets from Site 1 and Site 2

Site 1

Site 2

\begin{tabular}{|l|c|l|c|}
\hline \hline \multicolumn{1}{|c|}{ Observation } & $\begin{array}{c}\text { \%o of } \\
\text { Modules }\end{array}$ & \multicolumn{1}{|c|}{ Observation } & $\begin{array}{c}\text { \% of } \\
\text { Modules }\end{array}$ \\
\hline Glass (front): Lightly soiled & $55 \%$ & $\begin{array}{l}\text { Glass (front): Small, localized } \\
\text { damage }\end{array}$ & $50 \%$ \\
\hline Glass (front): Bird droppings & $24 \%$ & Wires: Pliable but degraded & $43 \%$ \\
\hline Connectors: Pliable but degraded & $22 \%$ & Glass (front): Lightly soiled & $43 \%$ \\
\hline Encapsulant: Major discoloration & $20 \%$ & Junction box: seal will leak & $36 \%$ \\
\hline Backsheet: Small, localized damage & $20 \%$ & $\begin{array}{l}\text { Thin film module: Distance } \\
\text { between frame and cells }<10 \mathrm{~mm}\end{array}$ & $36 \%$ \\
\hline
\end{tabular}

If the proposed visual inspection tool becomes widely adopted, a variety of data mining and analysis techniques may provide useful for understanding module degradation and failure. Basic analyses may include identification of the most frequently observed defects among a set of identical modules in a single location. An extension of this type of study might seek to identify which defects are more likely to be associated with decreased performance ratio and which defects are more likely to be benign, similar to the approach of Ref. [2]. More comprehensive studies could compare data from similar module types in a single location over time (c.f. Refs. $[3,4]$ ) or over multiple locations for the same amount of field exposure time. Comparison within and between these kinds of studies would be greatly simplified if identical types and amounts of data are collected and compiled in a similar manner. Degradation issues that arise from environmental exposure may be correlated with climate zone through the linkage of defect frequency with latitude and longitude data. Statistical analysis of very large sets of data may reveal more subtle connections between specific defects or groups of defects and their correlation with the electrical performance characteristics of modules. This type of data is currently in limited supply, though analytical frameworks for assessing reliability based on field degradation studies are in development (c.f. Ref. [1]). If visually observable defects can be correlated or conclusively linked with the measured electrical performance degradation rates, visual inspection may provide a relatively low impact method for assessing which PV installations may be more likely to see accelerated degradation based on the frequency and types of defects that develop.

\section{Conclusion}

This report summarizes our attempts to create a documentation aid for global data collection and aggregation of long-term PV degradation, especially with regard to climate zone-specific weathering. A data collection tool was developed, tested, and improved through the inspection of over 60 modules from a variety of technology types from more than 20 manufacturers and 
fielded at three different sites, and the input of professionals with decades of combined experience in the field. Details in this report and associated supplementary material are provided to aid identification of different defect types. Additionally, a preliminary analysis of data collected from two sites identifies the most commonly observed defects and suggests a wide assortment of future capabilities in data analysis and reduction if this inspection tool or something similar becomes widely adopted.

\section{Acknowledgements}

This work was supported by the U.S. Department of Energy under Contract No. DE-AC36-08GO28308 with the National Renewable Energy Laboratory. We also acknowledge the contributions of Ulrike Jahn (TÜV Rheinland Immissionsschutz und Energiesysteme GmbH, Germany), Karl Berger (Austrian Institute of Technology), Thomas Friesen (Scuola Universitaria Professionale della Svizzera Italiana), and Marc Koentges (Institut fuer Solarenergieforschung GmbH Hameln/Emmerthal) (Lead of IEA PVPS Task 13 Subtask 3.2) in developing the format and content of the data collection tool. Special thanks are also due to Cassius McChesney of Arizona Public Service for providing access to modules that were deployed there.

\section{References}

[1] M. Vazquez and I. Rey-Stolle, "Photovoltaic module reliability model based on field degradation studies," Progress in Photovoltaics, vol. 16, pp. 419-433, Aug 2008.

[2] P. Sanchez-Friera, et al., "Analysis of degradation mechanisms of crystalline silicon PV modules after 12 years of operation in Southern Europe," Progress in Photovoltaics, vol. 19, pp. 658-666, Sep 2011.

[3] E. D. Dunlop and D. Halton, "The performance of crystalline silicon photovoltaic solar modules after 22 years of continuous outdoor exposure," Progress in Photovoltaics, vol. 14, pp. 53-64, Jan 2006.

[4] T. Ishii, et al., "Long-term performance degradation of various kinds of photovoltaic modules under moderate climatic conditions," Progress in Photovoltaics, vol. 19, pp. 170-179, Mar 2011.

[5] J. Munoz, et al., "An Investigation into Hot-Spots in Two Large Grid-Connected PV Plants," Progress in Photovoltaics, vol. 16, pp. 693-701, Dec 2008.

[6] O. S. Sastry, et al., "Degradation in performance ratio and yields of exposed modules under arid conditions," in 26th European Photovoltaic Solar Energy Conference and Exhibition, Hamburg, Germany, 2011.

[7] D. Torp, private communication, 2011.

[8] T. Lombardo, et al., "Soiling of silica-soda-lime float glass in urban environment: measurements and modelling," Atmospheric Environment, vol. 39, pp. 989-997, Feb 2005.

[9] W. H. Holley, et al., "Investigation into the causes of browning in EVA encapsulated flat plate PV modules," 1994 IEEE First World Conference on Photovoltaic Energy Conversion/Conference Record of the Twenty Fourth IEEE Photovoltaic Specialists Conference-1994, Vols I and II, pp. 893-896, 1994. 
[10] M. Ezrin, et al., "Discoloration of EVA encapsulant in photovoltaic cells," Antec 95 - the Plastics Challenger: A Revolution in Education, Conference Proceedings, Vols I-III, pp. 3957-3960, 1995.

[11] M. Ezrin, et al., "Further studies of discoloration of EVA encapsulant in photovoltaic modules," Antec '96: Plastics - Racing into the Future, Vols I-III, vol. 42, pp. 3260-3264, 1996.

[12] W. H. Holley, et al., "UV stability and module testing of non-browning experimental PV encapsulants," Conference Record of the Twenty Fifth IEEE Photovoltaic Specialists Conference - 1996, pp. 1259-1262, 1996.

[13] P. Klemchuk, et al., "Investigation of the degradation and stabilization of EVA-based encapsulant in field-aged solar energy modules," Polymer Degradation and Stability, vol. 55, pp. 347-365, 1997.

[14] I. Rutschmann, "Unlocking the secret of snail trails," Photon International, pp. 114-125, 2012.

[15] T. J. McMahon, "Accelerated testing and failure of thin-film PV modules," Progress in Photovoltaics, vol. 12, pp. 235-248, Mar-May 2004.

[16] D. E. Carlson, et al., "Corrosion effects in thin-film photovoltaic modules," Progress in Photovoltaics, vol. 11, pp. 377-386, Sep 2003.

[17] D. DeGraaff, et al., "Degradation Mechanisms in Si Module Technologies Observed in the Field; Their Analysis and Statistics." NREL 2011 Photovoltaic Module Reliability Workshop, Golden, CO, 2011.

[18] IEC, "Photovoltaic devices- Part 1: Measurement of photovoltaic current-voltage characteristics," vol. 60904-1, 2006. 


\section{Documentation of module condition}

Date Name of data recorder

Location

Latitude Longitude Altitude

\section{System Data}

System design: $\quad \square$ single module $\square$ multiple modules (a.) $\square$ unknown

(a.) Multiple module system:

Module location/number in a series string (from negative) \# of modules in series (string) \# of strings in parallel (array)

\# of bypass diodes \# of modules per bypass diode

System Bias: $\square$ open circuit $\square$ resistive load $\square$ max. power tracked $\square$ short circuit $\square$ unknown

System Grounding: $\square$ grounded (a.) $\quad \square$ not grounded $\quad \square$ unknown
(a.) $\square$ negative
$\square$ positive
$\square$ center of string
$\square$ unknown

\section{BEGIN INSPECTION AT BACK SIDE OF MODULE}

\section{Module Data}

Technology: $\square$ mono Si $\square$ multi Si $\square$ a--Si $\quad \square$ CdTe $\square$ CIGS/CIS $\square$ other:

Certification: $\square$ unknown $\square$ UL $1703 \quad \square$ IEC $61215 \quad \square$ IEC $61646 \quad \square$ IEC 61730 $\square$ other:

Estimated deployment date

Photo taken of nameplate: $\square$ yes $\square$ no

Manufacturer

Model \#

Serial \#

Installation Site/Facility Serial \#

Width $\mathrm{cm}$ Length $\mathrm{cm}$

Nameplate: $\square$ nameplate missing

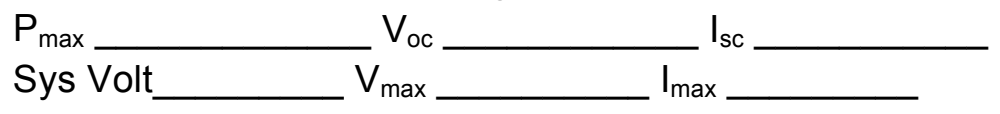

Bypass diode, $I_{f}$

Series fuse

\section{Rear-side Glass: $\square$ not applicable $\square$ applicable}

Damage: $\square$ no damage $\square$ small, localized $\square$ extensive 
Damage Type (mark all that apply):

$\square$ crazing or other non--crack damage

$\square$ shattered (tempered ) $\square$ shattered (non-tempered ) $\square$ cracked (a.) $\square$ chipped (b.)

(a.) Cracks (\#): $\square 1 \square 2 \square 3 \square 4--10 \square>10$

Crack(s) start from: $\square$ module corner $\square$ module edge $\square$ cell $\square$ junction box $\square$ foreign body impact location

(b.) Chips (\#): $\square 1 \square 2 \square 3 \square 4--10 \square>10$

Chipping location: $\square$ module corner $\square$ module edge

\title{
4. Backsheet: $\square$ not applicable $\square$ applicable
}

\author{
Appearance: $\square$ like new $\quad \square$ minor discoloration $\quad \square$ major discoloration \\ Texture: $\square$ like new $\square$ wavy (not delaminated) $\square$ wavy (delaminated) $\square$ dented \\ Material quality --chalking: $\square$ none $\quad \square$ slight $\square$ substantial \\ Damage: $\square$ no damage $\square$ small, localized $\square$ extensive \\ Damage Type (mark all that apply): \\ $\square$ burn marks (a.) $\square$ bubbles (b.) $\square$ delamination (c.) $\square$ cracks/scratches (d.) \\ (a.)Burn marks (\#): $\square 1 \square 2 \square 3 \square$ 4--10 $\square>10$ \\ Fraction of area burned: \\ $\square<5 \% \square 5--25 \% \square 50 \% \square 75 \%--100 \%$ (consistent overall) \\ (b.) Bubbles(\#): $\quad \square 1 \square 2 \square 3 \square 4--10 \square>10$ \\ Average bubble dimension: $\square<5 \mathrm{~mm} \square 5$-- $30 \mathrm{~mm} \square>30 \mathrm{~mm}$ \\ Fraction of area with bubbles $>5 \mathrm{~mm}$ : \\ $\square<5 \% \square 5--25 \% \square 50 \% \square 75 \%--100 \%$ (consistent overall) \\ (c.) Fraction of area delaminated: \\ $\square<5 \% \square 5--25 \% \square 50 \% \square 75 \%--100 \%$ (consistent overall) \\ Fraction of delamination that exposes circuit or cell(s) \\ $\square<5 \% \square 5--25 \% \square 50 \% \square 75 \%--100 \%$ (consistent overall) \\ (d.) Cracks/scratches (\#): $\square 1 \square 2 \square 3 \square 4--10 \square>10$ \\ Cracks/scratches location: $\square$ random/no pattern $\square$ over cells $\square$ between cells \\ Fraction of area affected by cracks/scratches (approx.): \\ $\square<5 \% \square 5--25 \% \square 50 \% \square 75 \%$--100\% (consistent overall) \\ Fraction of cracks/scratches that expose circuit (approx.): \\ ๑ $0 \% \square 25 \% \square 50 \% \square 75 \% \square 100 \%$
}

\section{Wires/Connectors:}

Wires: $\square$ not applicable $\square$ like new $\square$ pliable, but degraded $\square$ embrittled (mark all that apply): $\square$ cracked/disintegrated insulation $\square$ burnt

$\square$ corroded $\square$ animal bites/marks

Connectors: $\square$ not applicable $\square$ like new $\square$ pliable, but degraded $\square$ embrittled Type: $\square$ unsure $\square$ MC3 or MC4 $\square$ Tyco Solarlok $\square$ other 
(mark all that apply): $\square$ cracked/disintegrated insulation $\square$ burnt $\square$ corroded

\section{Junction Box:}

Junction box itself: $\square$ not applicable/observable $\square$ applicable

Physical state: $\square$ intact $\square$ unsound structure

(mark all that apply): $\square$ weathered $\square$ cracked $\square$ burnt $\square$ warped

Lid: $\square$ intact/potted $\square$ loose $\square$ fell off $\square$ cracked

Junction box adhesive: $\square$ not applicable/observable $\square$ applicable

Attachment: $\square$ well attached $\square$ loose/brittle $\square$ fell off

Pliability: $\square$ like new $\square$ pliable, but degraded $\square$ embrittled

Junction box wire attachments: $\square$ not applicable/observable $\square$ applicable

Attachment: $\square$ well attached $\square$ loose $\square$ fell off

Seal: $\square$ good seal $\square$ seal will leak

other: $\square$ arced/started a fire

\section{Frame Grounding:}

Original state: $\square$ Wired ground $\square$ Resistive ground $\square$ No ground $\square$ unknown

Appearance: $\square$ Not applicable $\square$ Like new $\quad \square$ Some corrosion $\square$ Major corrosion

Function: $\quad \square$ Well grounded $\square$ No connection

Photos taken of $\square$ back, label, and junction box

CONTINUE INSPECTION ON FRONT SIDE OF MODULE

\section{Frame: $\square$ not applicable $\square$ applicable}

Appearance: $\square$ like new $\square$ damaged (a.) $\quad \square$ missing

(a.) (mark all that apply): $\square$ minor corrosion $\square$ major corrosion $\square$ frame joint separation $\square$ frame cracking $\square$ bent frame $\square$ discoloration

Frame Adhesive: $\square$ like new/not visible $\square$ degraded (a.)

(a.) (mark all that apply): $\square$ adhesive oozed out $\square$ adhesive missing in areas

\section{Frameless Edge Seal: $\square$ not applicable $\square$ applicable}

Appearance: $\square$ like new $\square$ discoloration (a.) $\square$ visibly degraded

(a.) Fraction affected by discoloration:

$\square<5 \% \square 5--25 \% \square 50 \% \square 75 \%--100 \%$ (consistent overall)

Material problems:

$\square$ squeezed/pinched out $\quad \square$ shows signs of moisture penetration

Delamination: $\square$ none $\square$ area(s) delaminated (a.)

(a.) Fraction Delaminated:

$\square<5 \% \quad \square 5--25 \% \quad \square 50 \% \quad \square 75 \%--100 \%$ (consistent overall) 


\section{Glass/Polymer (front):}

Material: $\square$ glass $\square$ polymer $\quad \square$ glass/polymer composite $\quad \square$ unknown

Features: $\square$ smooth $\square$ slightly textured $\square$ pyramid/wave texture

$\square$ antireflection coating

Appearance: $\square$ clean $\square$ lightly soiled $\square$ heavily soiled

Location of soiling:

$\square$ locally soiled near frame:

$\square$ left $\square$ right $\square$ top $\square$ bottom $\square$ all sides

locally soiled on glass /bird droppings

Damage: $\square$ no damage $\square$ small, localized $\square$ extensive

Damage Type (mark all that apply):

$\square$ crazing or other non--crack damage

$\square$ shattered (tempered ) $\square$ shattered (non--tempered ) $\square$ Cracked (a.)

$\square$ Chipped (b.) $\square$ milky discoloration (c.)

(a.) Cracks (\#): $\square 1 \quad \square 2 \quad \square 3 \quad \square 4--10 \quad \square>10$

Crack(s) start from: $\square$ module corner $\square$ module edge $\square$ cell $\square$ junction box $\square$ foreign body impact location

(b.) Chips (\#): $\square 1 \quad \square 2 \quad \square 3 \quad \square$ 4--10 $\square>10$

Chipping location: $\square$ module corner $\square$ module edge

(c.) Fraction of area:

$\square<5 \% \quad \square 5-25 \% \quad \square 50 \% \quad \square 75 \%$-- 100\% (consistent overall)

\section{Metallization:}

Gridlines/Fingers: $\square$ not applicable/barely observable $\square$ applicable Appearance: $\square$ like new $\square$ light discoloration(a.) $\quad \square$ dark discoloration(a.)

(a.) Fraction of discoloration:
$\square<5 \%$
$\square$ 5-25\%
$\square 50 \%$
$75 \%-100 \%$ (consistent overall)

Busbars: $\square$ not applicable/not observable $\square$ applicable Appearance: $\square$ like new $\square$ light discoloration(a.) $\quad \square$ dark discoloration(a.)

(a.) Fraction of discoloration:

$\square<5 \% \quad \square 5-25 \% \quad \square 50 \% \quad \square 75 \%-100 \%$ (consistent overall)

(mark all that apply): $\square$ obvious corrosion $\square$ diffuse burn mark(s) $\square$ misaligned

Cell Interconnect Ribbon: $\square$ not applicable/not observable $\square$ applicable

Appearance: $\square$ like new $\square$ light discoloration(a.) $\quad \square$ dark discoloration(a.)

(a.) Fraction of discoloration:

$\square<5 \% \quad \square 5-25 \% \quad \square 50 \% \quad \square 75 \%-100 \%$ (consistent overall)

(mark all that apply): $\square$ obvious corrosion $\square$ burn marks $\square$ breaks

String Interconnect: $\square$ not applicable/not observable $\square$ applicable

Appearance: $\square$ like new $\quad \square$ light discoloration(a.) $\quad \square$ dark discoloration(a.)

(a.) Fraction of discoloration:

$\square<5 \% \quad \square 5-25 \% \quad \square 50 \% \quad \square 75 \%-100 \%$ (consistent overall)

(mark all that apply): $\square$ obvious corrosion $\square$ burn marks $\square$ breaks

$\square$ arc tracks (thin, small burns) 


\section{Silicon (mono or multi) module: $\square$ not applicable $\square$ applicable}

Number of:

Cells in module

Cells in series/string

Strings in parallel

Cell size: Width $\mathrm{cm}$ Length $\mathrm{cm}$

Distance between frame and cell: $\square>10 \mathrm{~mm} \square<10 \mathrm{~mm}$

Distance between cells in a string: $\square>1 \mathrm{~mm} \quad \square<1 \mathrm{~mm}$

Discoloration: $\quad \square$ none/like new $\square$ light discoloration $\square$ dark discoloration

Number of cells with any discoloration:

of those, average \% discolored area:

$\square<5 \% \quad \square 5-25 \% \quad \square 50 \% \quad \square 75 \%-100 \%$ (consistent overall)

Discoloration location(s) (mark all that apply):

$\square$ module center $\quad \square$ module edges $\quad \square$ cell centers $\quad \square$ cell edges

$\square$ over gridlines $\quad \square$ over busbars $\quad \square$ over tabbing $\quad \square$ between cells

$\square$ individual cell(s)darker than others $\quad \square$ partial cell discoloration

Junction box area: $\square$ same as elsewhere $\square$ more affected $\square$ less affected

Damage: $\square$ none

(mark all that apply): $\square$ burn mark (a.) $\square$ cracking (b.) $\square$ moisture

$\square$ worm marks/snail tracks (c.) $\square$ foreign particle embedded
(a.) Burns (\#): $\square 1 \quad \square 2 \quad \square 3 \quad \square$ 4-10 $\quad \square>10$
(b.) Number of cells cracked:
(c.) Number of cells with worm marks/snail tracks:

Delamination: $\square$ none $\square$ from edges $\square$ uniform $\square$ corner(s) $\square$ near junction box $\square$ between cells (a.) $\square$ over cells (b.) $\square$ near cell or string interconnect

(a.) Fraction delaminated between cells:

$\square<5 \% \quad \square 5-25 \% \quad \square 50 \% \quad \square 75-100 \%$ (consistent overall)

(b.) Fraction delaminated over cells:

$\square<5 \% \quad \square 5-25 \% \quad \square 50 \% \quad \square 75-100 \%$ (consistent overall)

Likely interface (choose 2):

$\square$ glass $\square$ semiconductor $\quad \square$ encapsulant $\square$ back sheet $\square$ busbar

\section{Thin film module: $\square$ not applicable $\square$ applicable}

Number of cells:

Number of cells in module

Number of cells in series/string

Number of strings in parallel

Cell size: Width $\mathrm{cm}$ Length $\mathrm{cm}$

Distance between frame and cell: $\square>10 \mathrm{~mm} \quad \square<10 \mathrm{~mm}$

Appearance: $\square$ like new $\square$ minor/light discoloration $\square$ major/dark discoloration

Discoloration type (mark all that apply):

$\square$ spotted degradation $\quad \square$ haze (encapsulant browning) $\quad \square$ other 
Discoloration location (mark all that apply):

$\square$ overall/no location pattern $\quad \square$ module center $\quad \square$ module edge(s)

$\square$ cell center $\quad \square$ cell edges $\quad \square$ near crack(s)

Damage: $\square$ no damage $\square$ small, localized $\square$ extensive

Damage Type (mark all that apply): $\square$ burn mark(s) $\square$ cracking

$\square$ possible moisture $\square$ foreign particle embedded

Delamination: $\square$ no delamination $\square$ small, localized $\quad \square$ extensive

Location: $\square$ from edges $\square$ uniform $\square$ corner(s) $\square$ near junction box $\square$ near busbar

$\square$ along scribe lines

Delamination Type: $\square$ absorber delamination $\square$ AR coating delamination $\square$ other

\section{Photos taken of $\square$ front and defects}

14. Electronic Records $\square$ not applicable $\square$ applicable

Photographs and I--V curves recorded electronically--list file names in blanks

Photo files

I--V curve

Connector function: $\square$ functions $\square$ no longer mates $\square$ exposed

Irradiance __ Sensor

Temperature __ Sensor

EL picture

IR picture

Bypass Diode Test: $\square$ not applicable $\square$ applicable

Number of diodes:

In total , shorted , open

\section{OTHER}




\title{
ONREL
}

\section{Cataloging Module Condition by Visual Inspection A2. Photographic Examples}

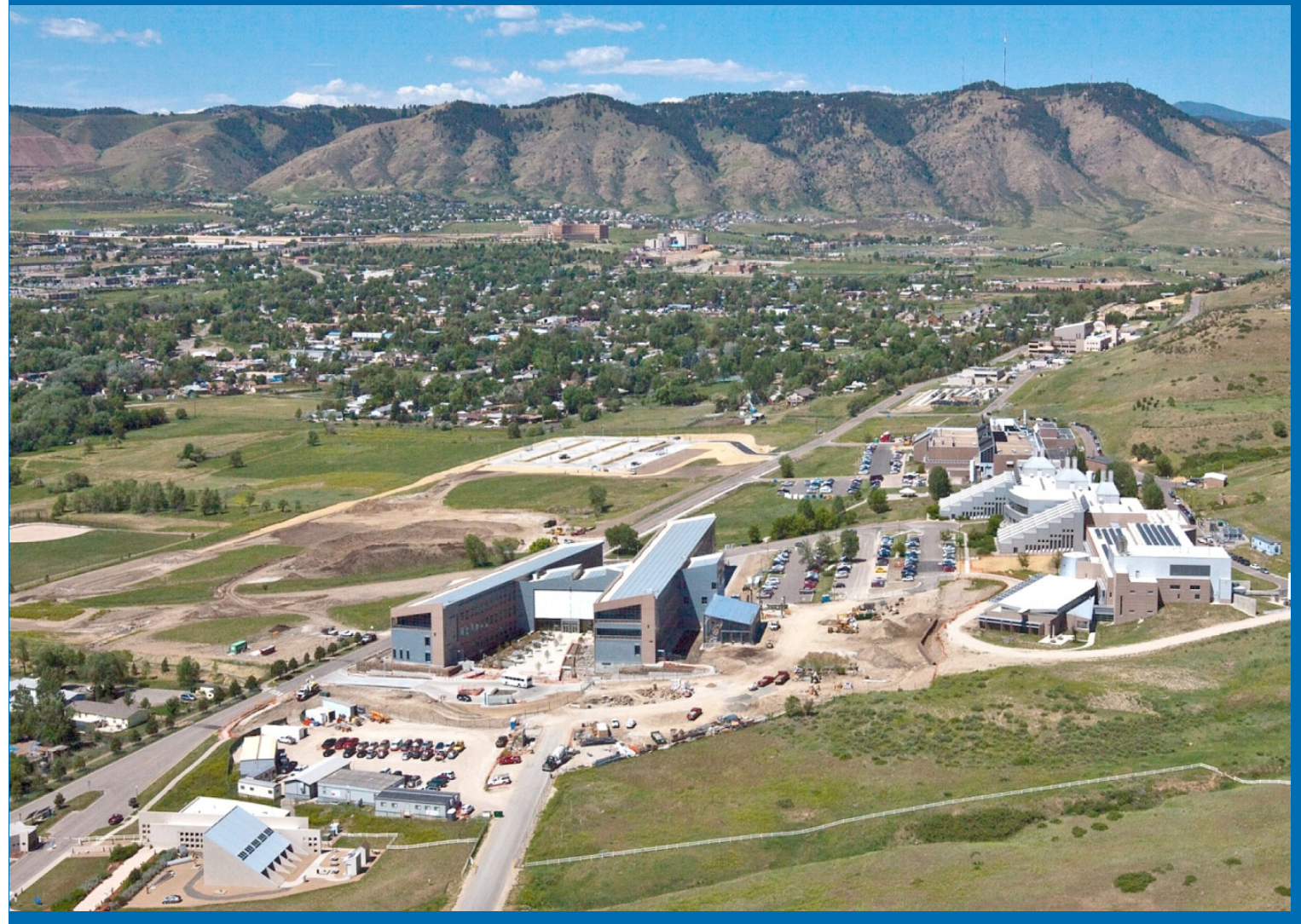

\author{
C.E. Packard
}

NREL, Colorado School of Mines

J. Wohlgemuth, S. Kurtz NREL

$4 / 2012$

NREL is a national laboratory of the U.S. Department of Energy, Office of Energy Efficiency and Renewable Energy, operated by the Alliance for Sustainable Energy, LLC. 


\section{Overview of Visual Inspection Checklist}

-Uses IEC/UL standard terminology

-Attempts to balance collection of sufficient detail for failure mode evaluation against minimizing recording time per module

-Consists of 14 sections- based on module component

- This presentation provides example photographs for training purposes

- Additional detail can be found in the full NREL report 


\section{System Data}

\section{Documentation of module condition}

Date Name of data recorder

Location

Latitude Longitude

Altitude

\section{System Data}

System design: $\quad \square$ single module $\square$ multiple modules $\square$ unknown

Multiple module system: $\square$ not applicable

Module location/number in a series string (from negative)

\# of modules in series (string) \# of strings in parallel (array)

\# of bypass diodes___ \# of modules per bypass diode

System Bias: $\square$ open circuit $\square$ resistive load $\square$ max. power tracked $\square$ short circuit $\square$ unknown

System Grounding: $\square$ negative $\square$ positive $\square$ center tap on one $\square$ unknown

BEGIN INSPECTION AT BACK SIDE OF MODULE 


\section{Module Data}

\section{Module Data}

Technology: $\square$ mono Si $\square$ multi Si $\square$ a--Si $\square$ CdTe $\square$ ClGS/CIS $\square$ other:

Certified:므unknown $\square$ UL 1703 IEC 61215 IEC $61646 \quad$ IIEC 61730 $\square$ other: $\quad$ As indicated on nameplate

Estimated deployment date

Photo taken of nameplate: $\nabla$ yes $\square$ no

Manufacturer

Model \#

Serial \#

Installation Site/Facility Serial \#

Width $\mathrm{cm}$ Length $\mathrm{cm}$

Nameplate: $\square$ nameplate missing

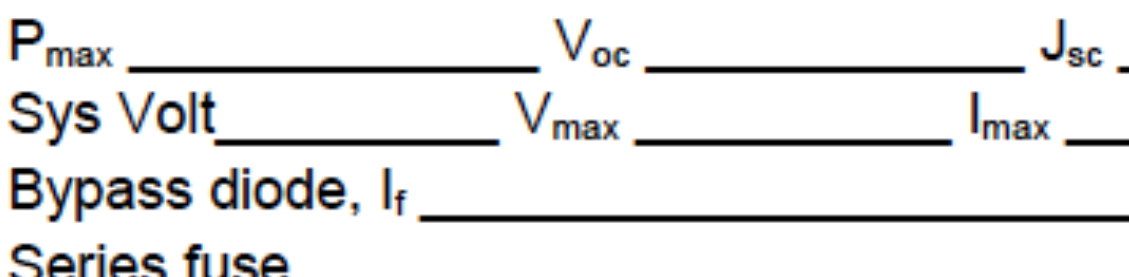

SHARP

SOLAR MODULE NT-175U1

THE ELECTRICAL CHAPACTERISTICS ARE WITHIN $\neq 10$ PERCENT OF THE INDICATED VALUES OF ISC, Voc. AND Pwax UNDE STANDARD TEST CONDITIONS
(IRRADIANCE OF $1000 \mathrm{~W} / \mathrm{m}^{2}$, AM1.5 SPECTRUM AND CELL TEMPERATURE OF $25^{\circ} \mathrm{C}$ ) MAXMUMM POWEA

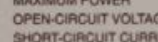

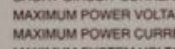

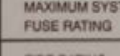
FiRE RATTMS FIELO WIANO SEPMUL No

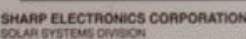

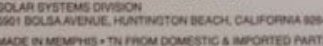
(40) HIN \pm 10 PERCENT and cell

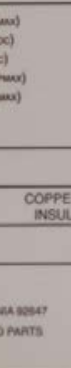
$J_{\mathrm{sc}}$

Sys Volt $\longrightarrow$ Series fuse 


\section{Rear-side Glass}

\section{Rear-side Glass: $\square$ not applicable $\square$ applicable}

Damage: $\square$ no damage $\square$ small, localized $\square$ extensive

Damage Type (mark all that apply):

$\square$ crazing or other non--crack damage

$\square$ shattered (tempered ) $\square$ shattered (non-tempered ) $\square$ Cracked (a.) $\square$ Chipped (b.)

(a.) Cracks (\#): $\square 1 \square 2 \square 3 \square 4--10 \square>10$

Crack(s) start from: $\square$ module corner $\square$ module edge $\square$ cell $\square$ junction box

(b.) Chips (\#): $\square 1 \square 2 \square 3 \square 4--10 \square>10$

Chipping location: $\square$ module corner $\square$ module edge

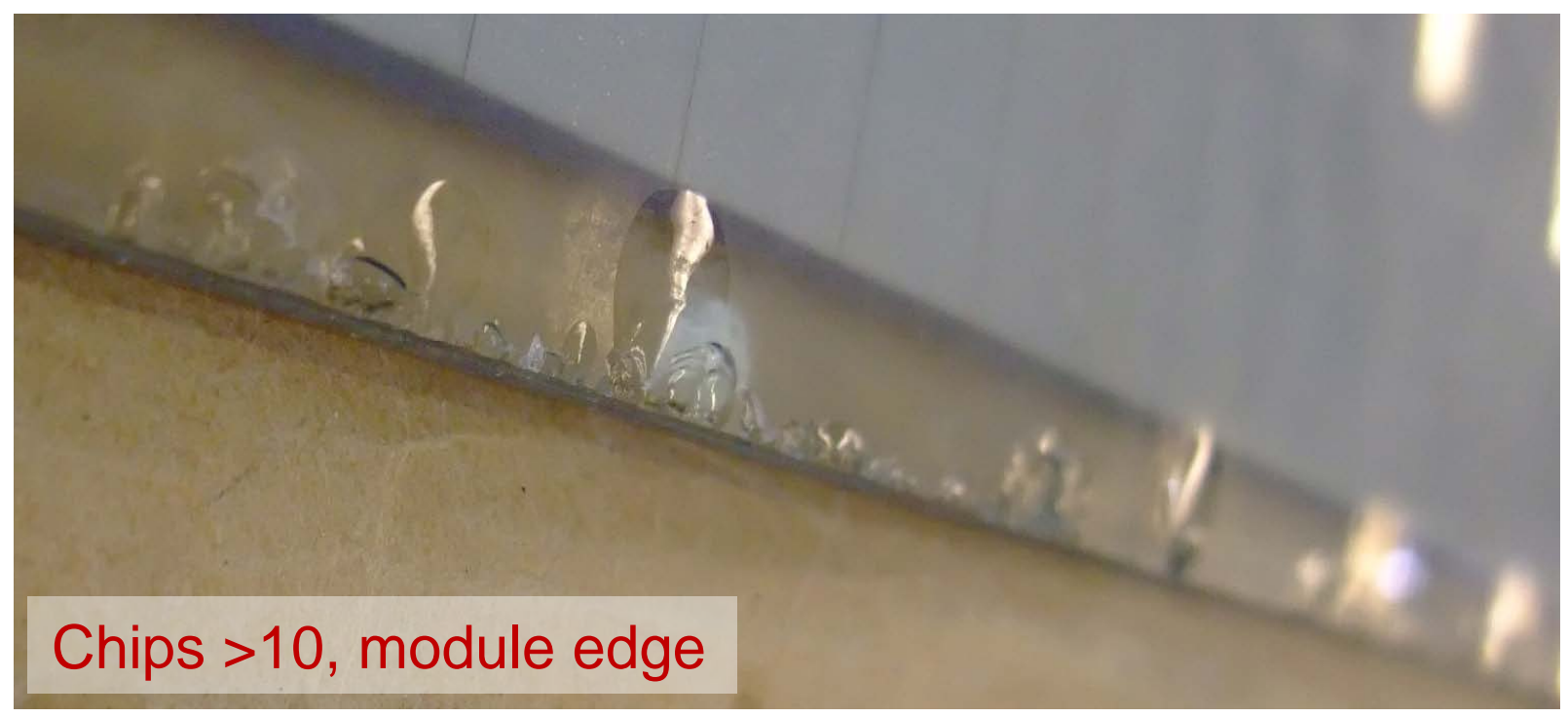




\section{Backsheet}

\section{Backsheet: $\square$ not applicable $\square$ applicable}

Areas missing

(record as delamination)

Appearance: $\square$ like new $\square$ minor discoloration $\square$ major discoloration

Texture: $\square$ like new $\square$ wavy (not delaminated) $\square$ wavy (delaminated) $\square$ dented Material quality --chalking: $\square$ none $\square$ slight $\square$ substantial

Damage: $\square$ no damage $\square$ small, localized $\square$ extensive

Damage Type (mark all that apply):

$\square$ burn marks (a.) $\square$ bubbles (b.) $\square$ delamination (c.) $\square$ cracks/scratches (d.)
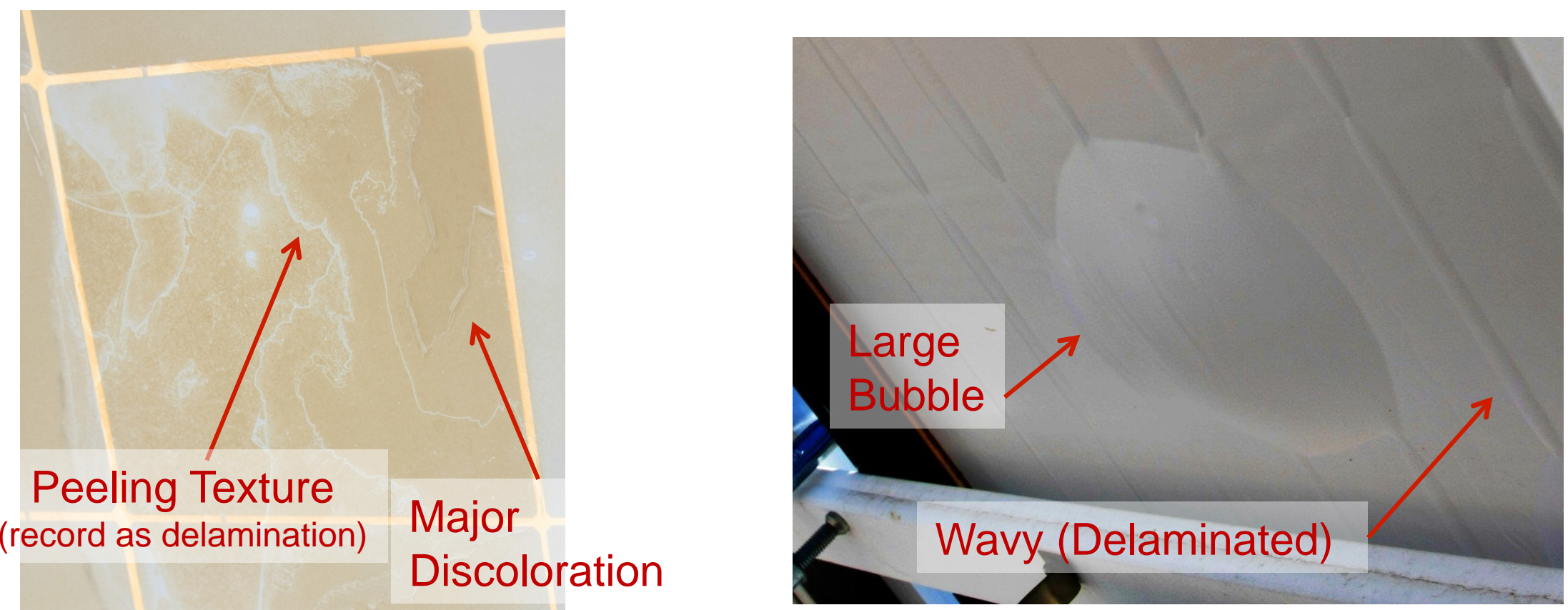


\section{Backsheet- Detail on Damage Type}

Damage Type (mark all that apply):

$\nabla$ burn marks (a.) $\square$ bubbles (b.) $\square$ delamination (c.) $\square$ cracks/scratches (d.)

(a.)Burn marks (\#): $\square 1$ 『/2 $\square 3 \square 4--10 \square>10$

Fraction of area burned:

$\checkmark<5 \% \square 5--25 \% \square 50 \% \square 75 \%--100 \%$ (consistent overall)

(b.) Bubbles(\#): $\quad \square 1 \square 2 \square 3 \square 4--10 \square>10$

Average bubble dimension: $\square<5 \mathrm{~mm} \square 5$--30 mm $\square>30 \mathrm{~mm}$

Fraction of area with bubbles $>5 \mathrm{~mm}$ :

$\square<5 \% \square 5--25 \% \square$ 50\% $\square$ 75\% --100\% (consistent overall)

(c.) Fraction of area delaminated:

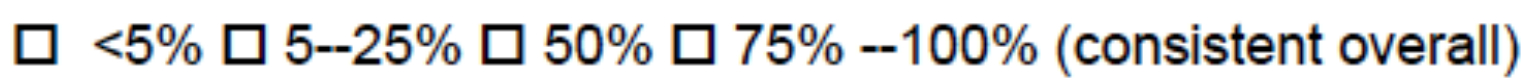

Fraction of delamination that exposes circuit or cell(s)

$\square<5 \% \square 5--25 \% \square 50 \% \square 75 \%-100 \%$ (consistent overall)

(d.) Cracks/scratches (\#): $\square 1 \square 2 \square 3 \square$ 4--10 $>>10$

Cracks/scratches location: $\square$ random/no pattern $\square$ over cells $\square$ between cells

Fraction of area affected by cracks/scratches (approx.):

$\square<5 \% \square 5--25 \% \square 50 \% \square 75 \%-100 \%$ (consistent overall)

Fraction of cracks/scratches that expose circuit (approx.):

$0 \% \square 25 \% \square 50 \% \square 75 \% \square 100 \%$ 


\section{Wires/ Connectors}

\section{Wires/Connectors:}

Wires: $\square$ not applicable $\square$ like new $\square$ pliable, but degraded $\square$ embrittled (mark all that apply): $\square$ cracked/disintegrated insulation $\square$ burnt $\square$ corroded $\square$ animal bites/marks

Connectors: $\square$ not applicable $\square$ like new $\square$ pliable, but degraded $\square$ embrittled Type: $\square$ unsure $\square$ MC3 or MC4 $\square$ Tyco Solarlok $\square$ other (mark all that apply): $\square$ cracked/disintegrated insulation $\square$ burnt $\square$ corroded

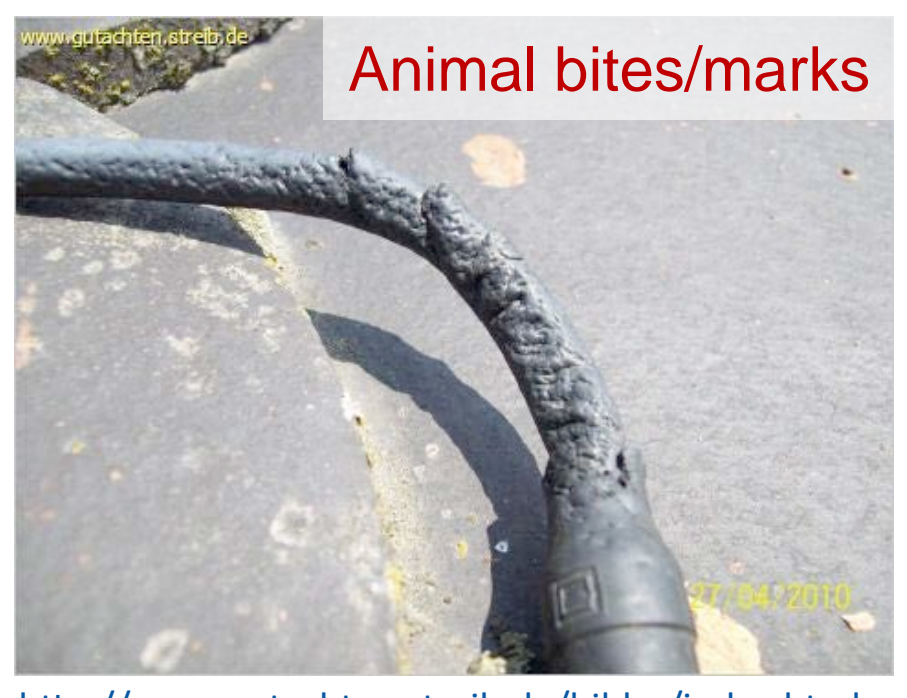

http://www.gutachten.streib.de/bilder/index.html
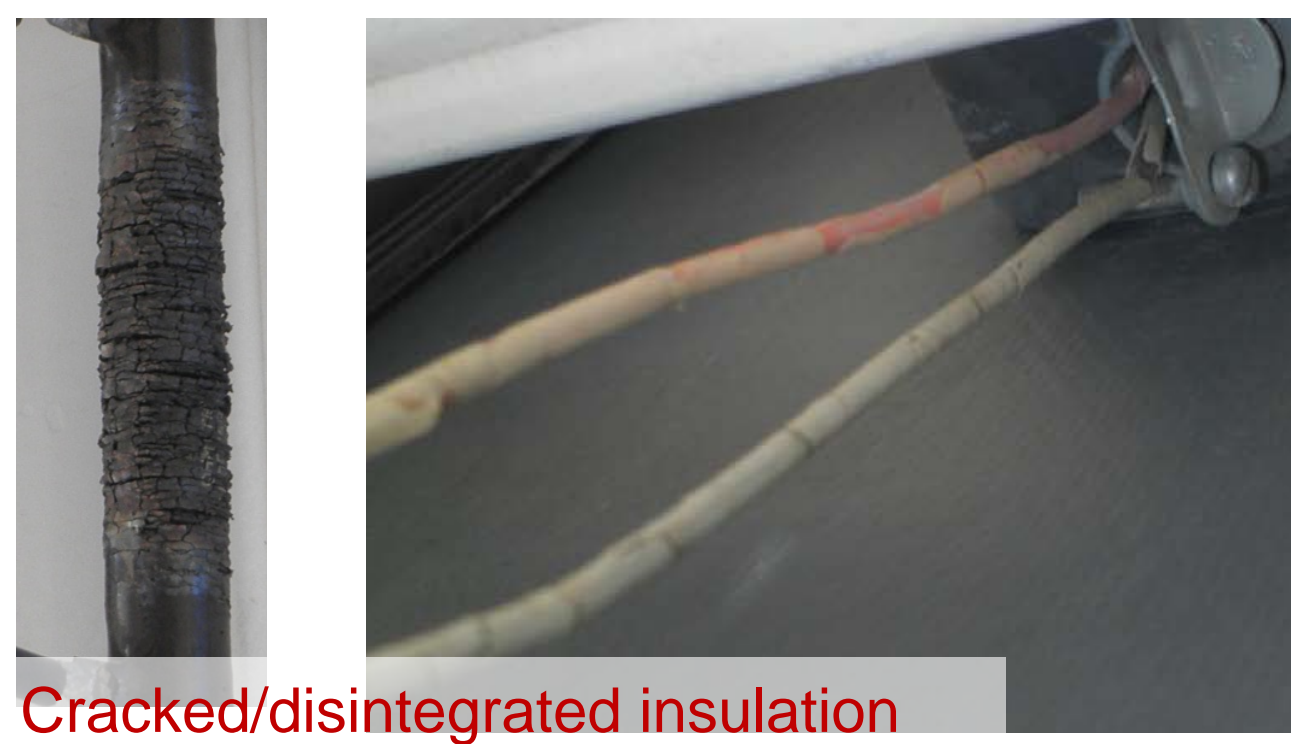


\section{Wires/ Connectors}

Connectors: $\square$ not applicable $\square$ like new $\square$ pliable, but degraded $\square$ embrittled Type: $\square$ unsure $\square$ MC3 or MC4 $\square$ Tyco Solarlok $\square$ other (mark all that apply): $\square$ cracked/disintegrated insulation $\square$ burnt $\square$ corroded
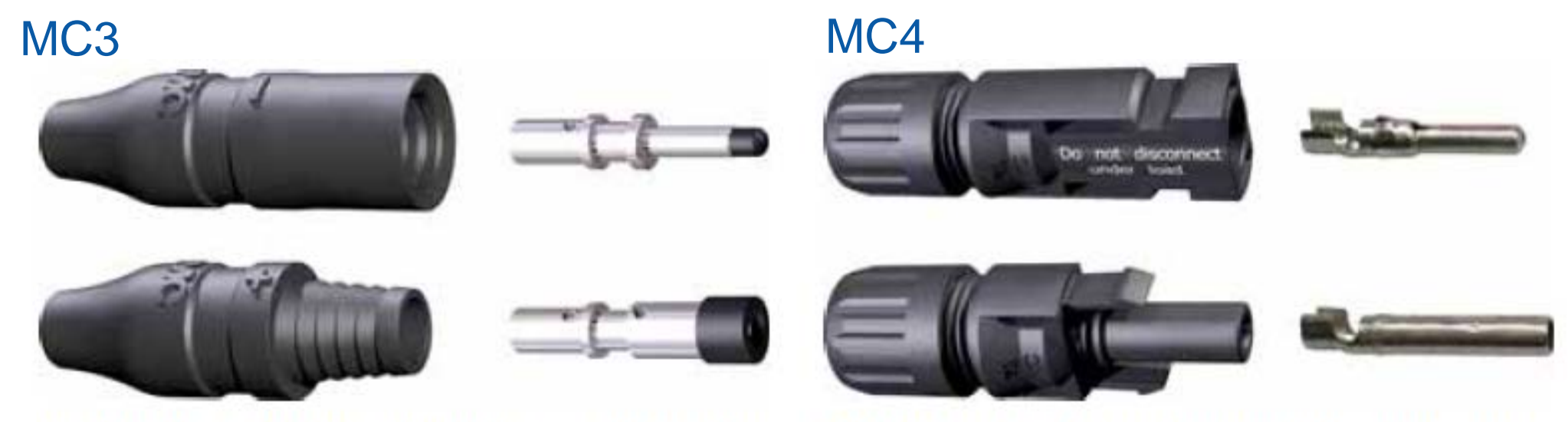

Tyco Solarlok

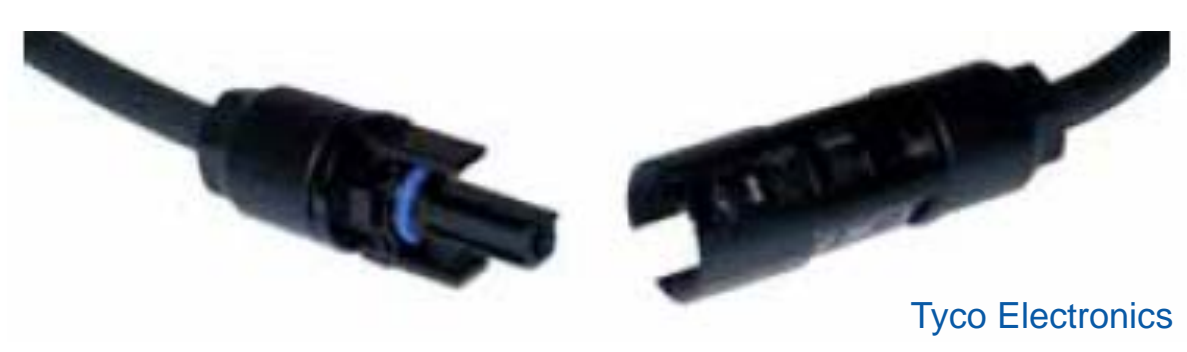




\section{Junction Box}

\section{Junction Box:}

Junction box itself: $\square$ not applicable/observable $\square$ applicable

Physical state: $\square$ intact $\square$ unsound structure

(mark all that apply): $\square$ weathered $\square$ cracked $\square$ burnt $\square$ warped

Lid: $\square$ intact/potted $\square$ loose $\square$ fell off $\square$ cracked

Junction box adhesive: $\square$ not applicable/observable $\square$ applicable

Attachment: $\square$ well attached $\square$ loose/brittle $\square$ fell off

Pliability: $\square$ like new $\square$ pliable, but degraded $\square$ embrittled

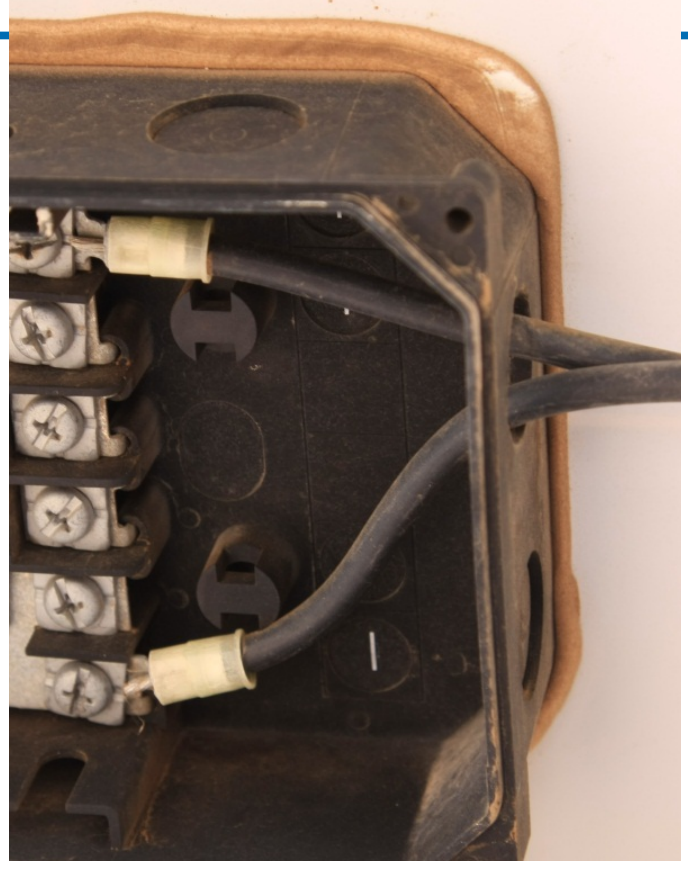

Junction box wire attachments: $\square$ not applicable/observable $\square$ applicable

Attachment: $\square$ well attached $\square$ loose $\square$ fell off

Seal: $\square$ good seal $\square$ seal will leak

other: $\square$ arced/started a fire 


\section{Frame Grounding}

\section{Frame Grounding:}

Original state: $\square$ Wired ground $\quad \square$ Resistive ground $\square$ No ground $\square$ unknown Appearance: $\square$ N/A $\quad \square$ Like new $\square$ Some corrosion $\square$ Major corrosion Function: $\quad \square$ Well grounded $\square$ No connection

Photos taken of $\square$ back, label, and junction box

CONTINUE INSPECTION ON FRONT SIDE OF MODULE 


\section{Frame}

\section{Frame: $\square$ not applicable $\square$ applicable}

Appearance: $\square$ like new $\quad \square$ bent $\quad \square$ discolored $\square$ missing

(mark all that apply): $\square$ minor corrosion $\square$ major corrosion $\square$ frame joint separation

$\square$ frame cracking

Frame Adhesive: $\square$ like new/not visible $\square$ degraded

(mark all that apply): $\square$ adhesive oozed out $\square$ adhesive missing in areas

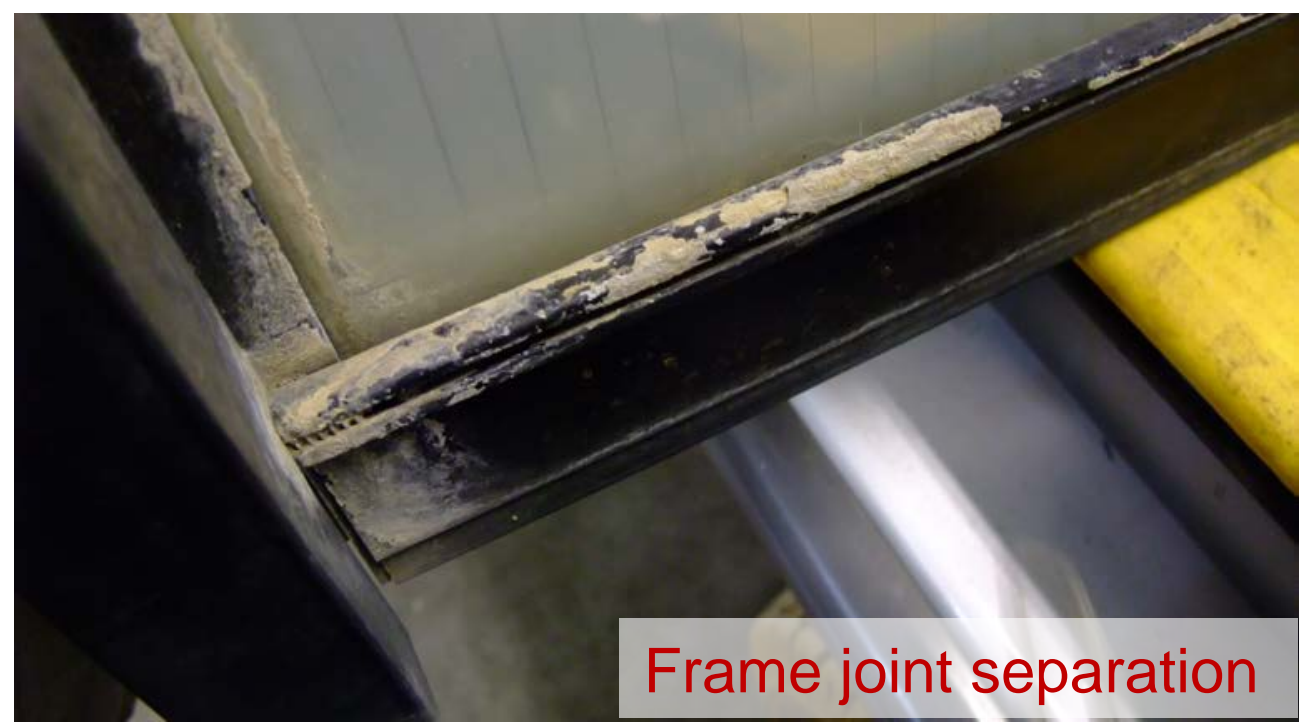




\section{Frameless Edge Seal}

9. Frameless Edge Seal: $\square$ not applicable $\square$ applicable

Bead of Silicone Around Module Edges Not an Edge Seal- NOT Applicable
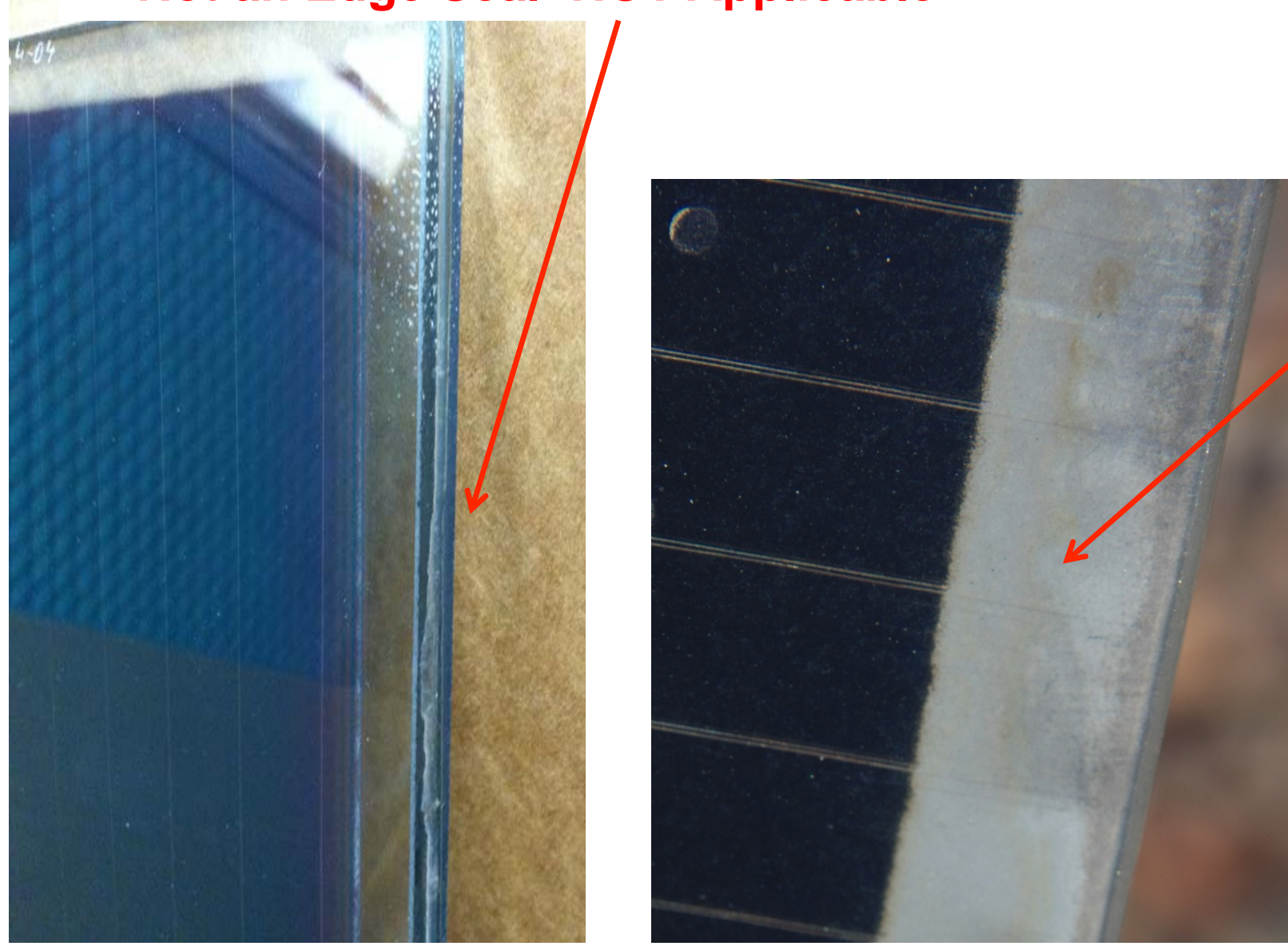

White or Gray Polymeric Sealant Around Module Edge Seal- Applicable

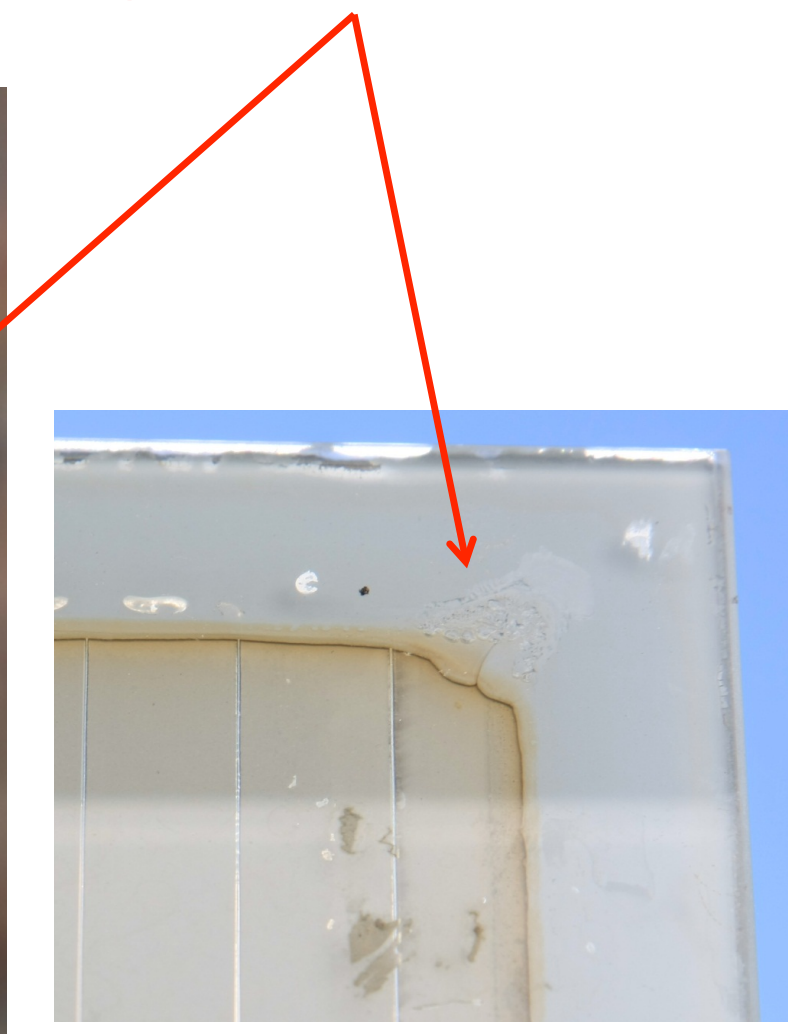




\section{Frameless Edge Seal}

\section{Frameless Edge Seal: $\square$ not applicable $\square$ applicable}

Appearance: $\square$ like new $\square$ discoloration (a.) $\square$ visibly degraded

(a.) Fraction affected by discoloration:

口 <5\% प 5--25\% प 50\% प 75\% --100\% (consistent overall)

Material problems:

口 squeezed/pinched out

$\square$ shows signs of moisture penetration

Delamination: $\square$ local only $\square$ widespread

Fraction Delaminated: $\square<5 \% \quad \square \quad 5--25 \% \quad \square \quad 50 \% \quad \square 75 \%$--100\% (consistent overall)
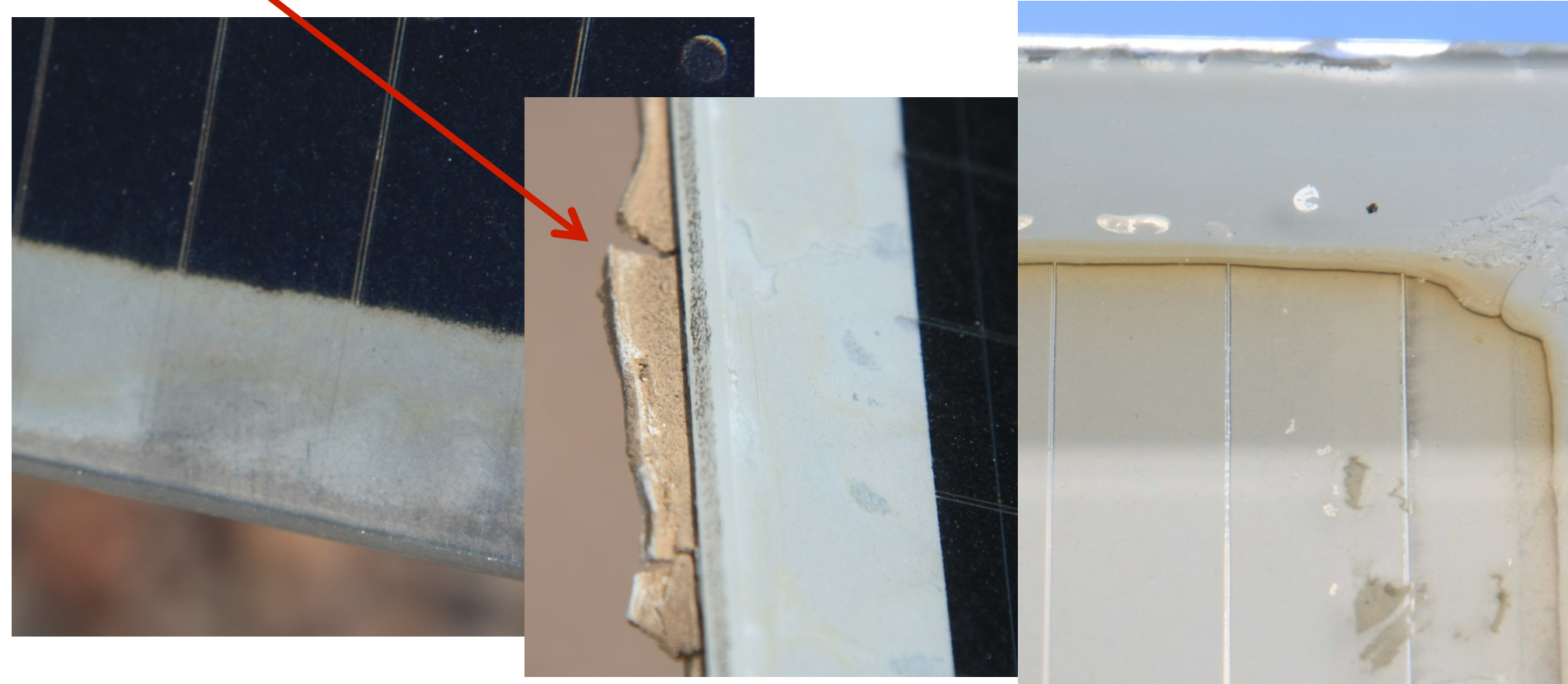


\section{Glass/Polymer (front)}

\section{Glass/Polymer (front):}

Material: $\nabla$ glass $\square$ polymer $\square$ glass/polymer composite $\square$ unknown

Features: $\square$ smooth $\square$ slightly textured $\square$ pyramid/wave texture $\square$ antireflection coating

Appearance: $\square$ clean $\nabla$ lightly soiled $\square$ heavily soiled

Location of soiling:

$\square$ locally soiled near frame:

$\square$ left $\square$ right $\square$ top $\square$ bottom $\square$ all sides

$\square$ locally soiled on glass /bird droppings

Damage: $\square$ no damage $\nabla$ small, localized $\square$ extensive

Damage Type (mark all that apply):

$\nabla$ crazing or other non--crack damage

$\square$ shattered (tempered ) $\square$ shattered (non--tempered ) $\square$ Cracked (a.)

$\square$ Chipped (b.) $\square$ milky discoloration (c.)

(a.) Cracks (\#): $\square 1 \quad \square 2 \quad \square 3 \quad \square 4--10 \quad \square>10$

Crack(s) start from: $\square$ module corner $\square$ module edge $\square$ cell $\square$ junction box

(b.) Chips (\#): $\square 1 \quad \square 2 \quad \square 3 \quad \square 4--10 \quad \square>10$

Chipping location: $\square$ module corner $\square$ module edge

(c.) Fraction of area:

$\square<5 \% \quad \square 5-25 \% \quad \square 50 \% \quad \square 75 \%$ - $100 \%$ (consistent overall) 


\section{Glass/Polymer (front)}

\section{Glass/Polymer (front):}

Material: $\nabla$ glass $\square$ polymer $\square$ glass/polymer composite $\square$ unknown

Features: $\square$ smooth $\square$ slightly textured $\square$ pyramid/wave texture $\square$ antireflection coating

Appearance: $\square$ clean $\nabla$ lightly soiled $\square$ heavily soiled Location of soiling:

$\nabla$ locally soiled near frame:

$\square$ left $\square$ right $\square$ top $\nabla$ bottom $\square$ all sides $\square$ locally soiled on glass /bird droppings

Damage: $\square$ no damage $\square$ small, localized $\square$ extensive Damage Type (mark all that apply):

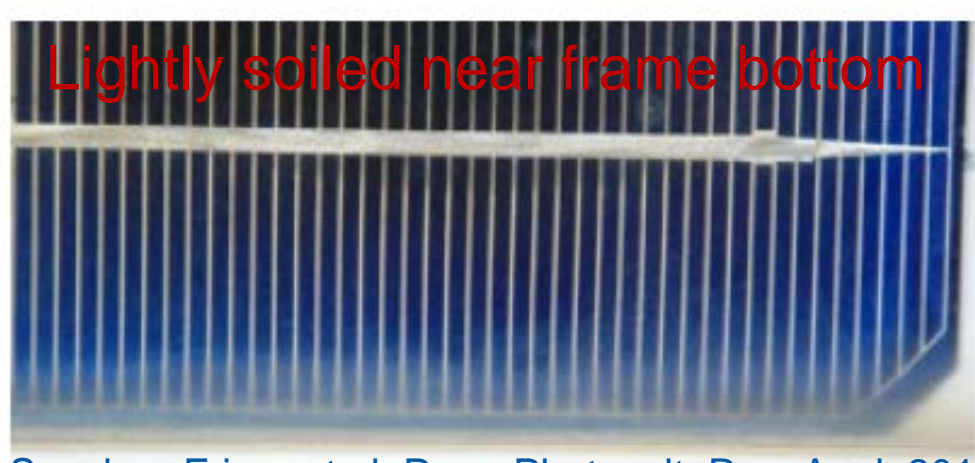

Sanchez-Friera et al. Prog. Photovolt: Res. Appl. 2011

$\square$ crazing or other non--crack damage

$\square$ shattered (tempered ) $\square$ shattered (non--tempered ) $\square$ Cracked (a.)

$\square$ Chipped (b.) $\square$ milky discoloration (c.)

(a.) Cracks (\#): $\square$ ㄴ $\square 3 \quad \square 4--10 \quad \square>10$

Crack(s) start from: $\square$ module corner $\square$ module edge $\square$ cell $\square$ junction box

(b.) Chips (\#): $\begin{array}{lllll}\square & \square 2 & \square & \mathbf{3} 4-10 \quad \square>10\end{array}$

Chipping location: $\square$ module corner $\square$ module edge

(c.) Fraction of area:

$\square<5 \% \quad \square 5-25 \% \quad \square 50 \% \quad \square 75 \%-100 \%$ (consistent overall)

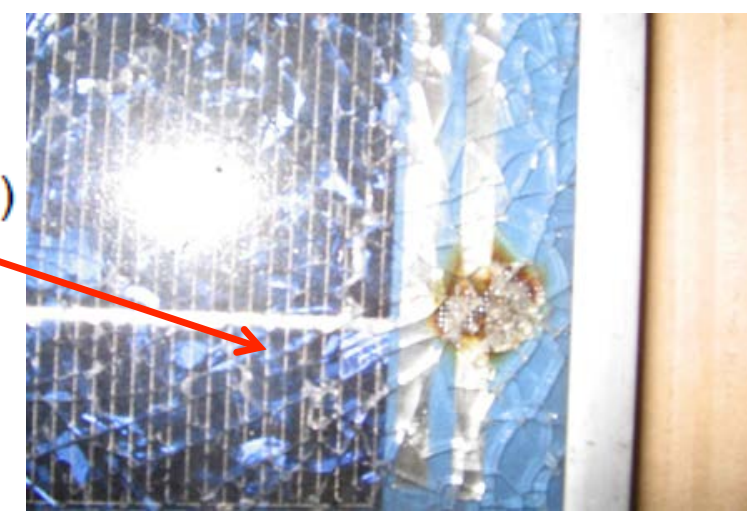




\section{Metallization- Clarification of Terminology}

Up to 4 levels of metallization and interconnects considered:

1. Gridlines/Fingers- finest level of metallization, $<1 \mathrm{~mm}$ thick

2. Busbars- connect gridlines/fingers within a single cell; often obscured by cell interconnect ribbon

3. Cell Interconnect Ribbon- connects multiple cells into a string

4. String Interconnect- connects multiple strings of cells

On an individual silicon cell

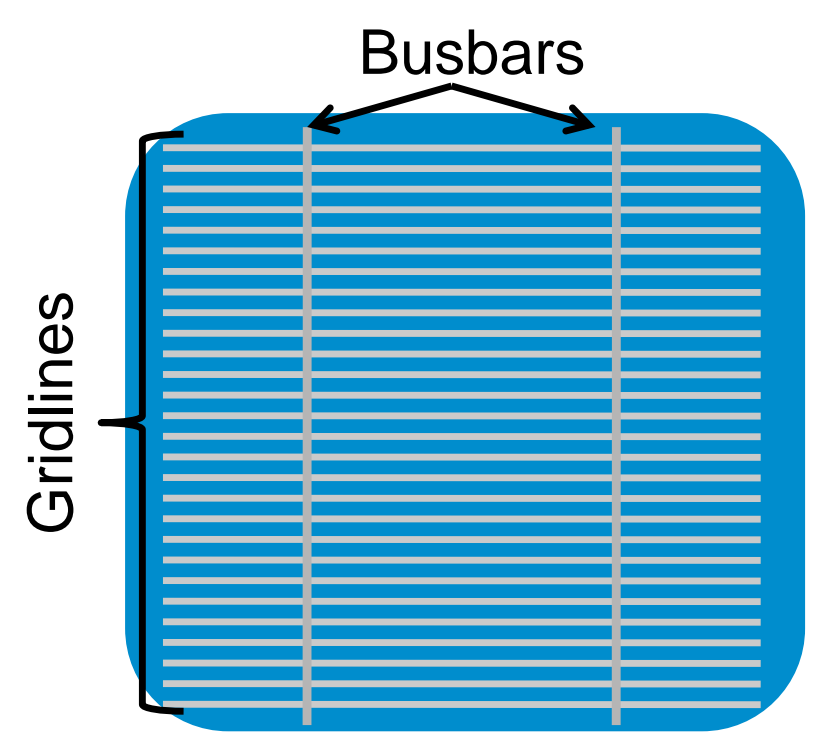

On a silicon module

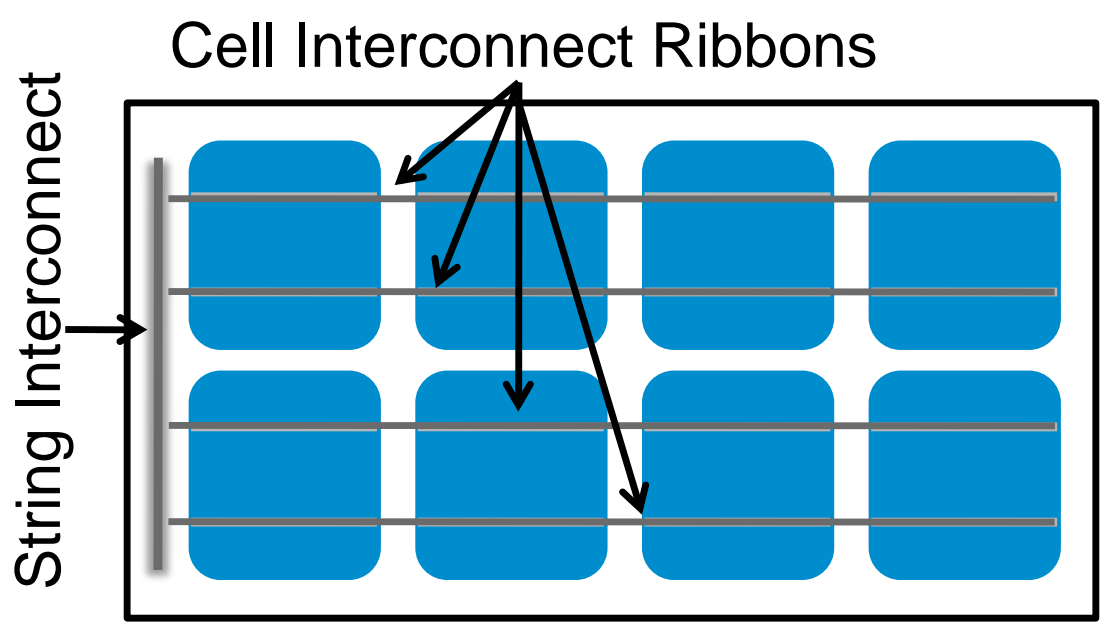

Note: The condition of the busbars is often unobservable due to the overlap of the cell interconnect ribbon

For thin film modules-

Consider function of metallization; generally will not use all 4 levels 


\section{Metallization}

\section{Metallization:}

Gridlines/Fingers: $\square$ not applicable/barely observable $\square$ applicable Appearance: $\square$ like new $\nabla$ light discoloration(a.) $\square$ dark discoloration(a.)

(a.) Fraction of discoloration:
$\square<5 \%$
ㅁ $5-25 \%$
$\square 50 \%$
ㅁ $75 \%-100 \%$ (consistent overall)

Busbars: $\square$ not applicable/not observable $\square$ applicable Appearance: $\square$ like new $\square$ light discoloration(a.) $\quad \nabla$ dark discoloration(a.) (a.) Fraction of discoloration:
$\square<5 \%$
ㄷ $5-25 \%$
ㅁ $50 \%$
ㅁ $75 \%-100 \%$ (consistent overall)

(mark all that apply): $\square$ obvious corrosion $\nabla$ diffuse burn mark(s) $\square$ misaligned

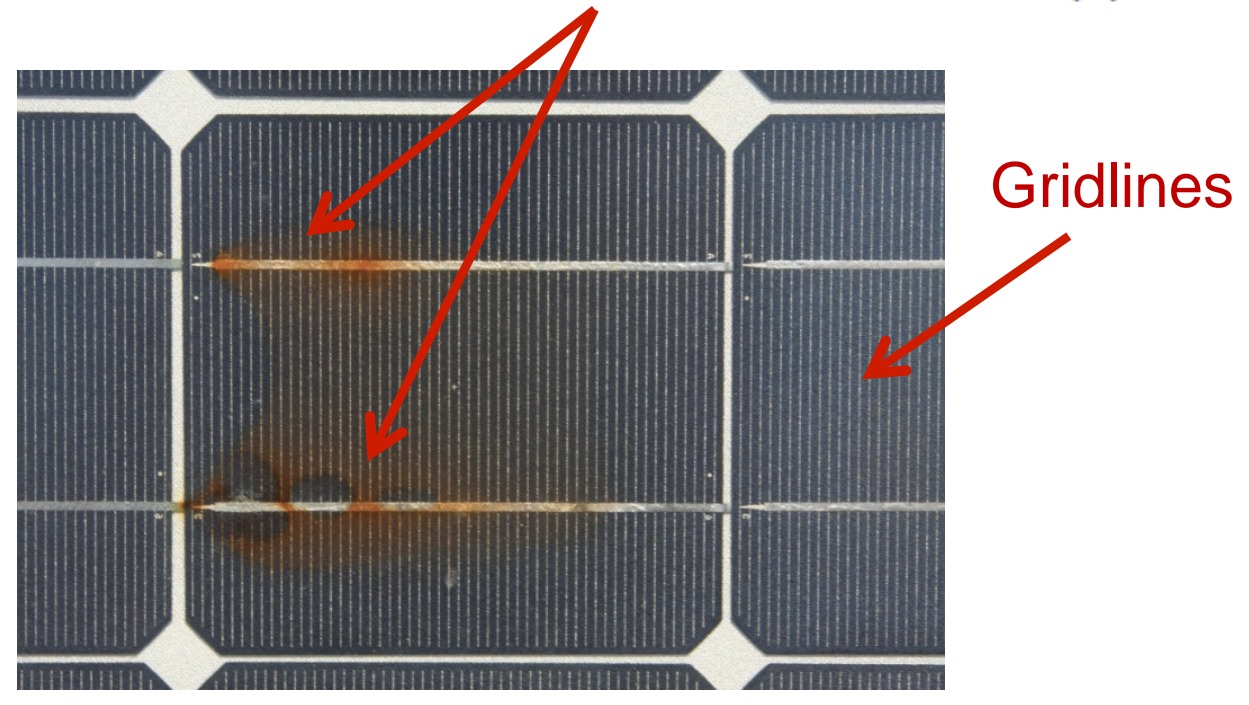




\section{Metallization}

Cell Interconnect Ribbon: $\square$ not applicable/not observable $\varangle$ applicable Appearance: $\nabla$ like new $\square$ light discoloration(a.) $\square$ dark discoloration(a.)

(a.) Fraction of discoloration:
ㄷ $<5 \%$
ㄷ $5-25 \%$
$\square 50 \%$
ㅁ 75\% - 100\% (consistent overall)

(mark all that apply): $\square$ obvious corrosion $\square$ burn marks $\square$ breaks

String Interconnect: $\square$ not applicable/not observable $\nabla$ applicable

Appearance: $\square$ like new $\square$ light discoloration(a.) $\quad \nabla$ dark discoloration(a.)

(a.) Fraction of discoloration:

$\square<5 \%$ $5-25 \%$ प $50 \%$ प $75 \%-100 \%$ (consistent overall)

(mark all that apply): $\square$ obvious corrosion $\nabla$ burn marks $\square$ breaks

$\square$ arc tracks (thin, small burns)

Dark Discoloration on String Interconnect

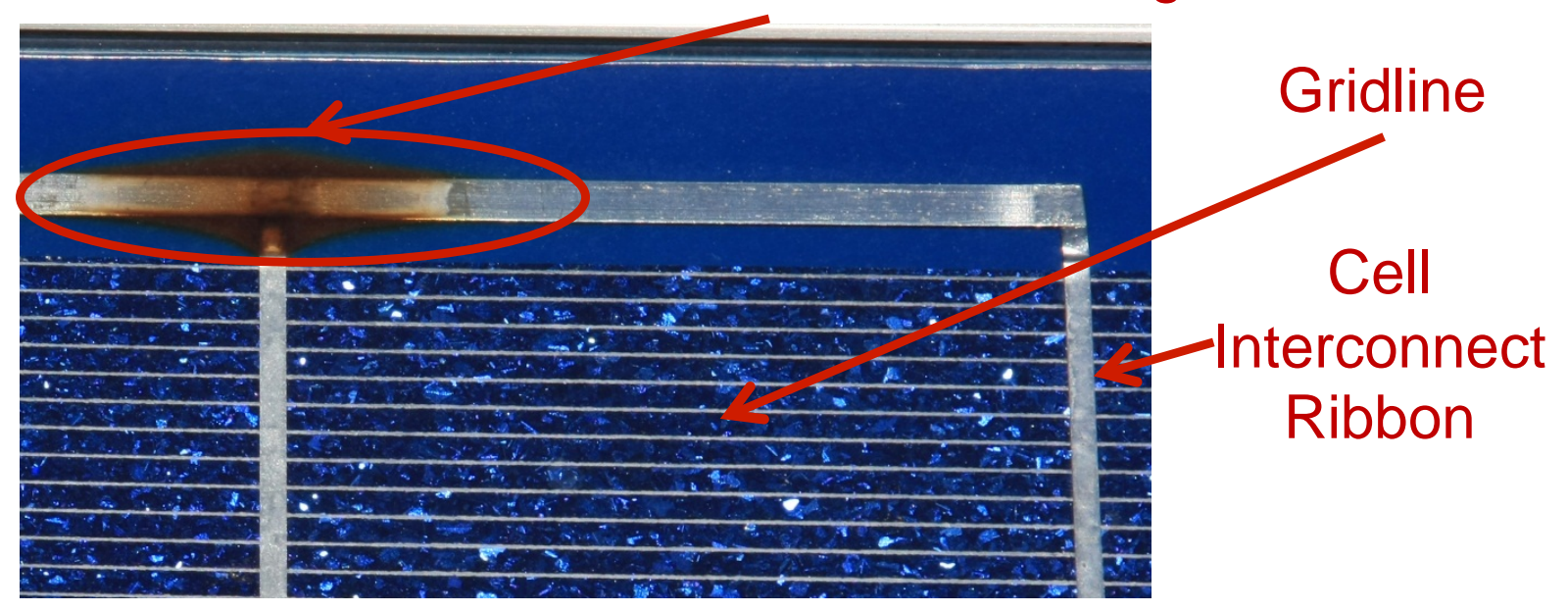




\section{Silicon Module: Cells}

12. Silicon (mono or multi) module: $\square$ not applicable $\square$ applicable

Number of:

Cells in module

Cells in series/string

Strings in parallel

Cell size: Width $\mathrm{cm}$ Length $\mathrm{cm}$

Distance between frame and cell: $\square>10 \mathrm{~mm} \quad \square<10 \mathrm{~mm}$

Distance between cells in a string: $\square>1 \mathrm{~mm} \quad \square<1 \mathrm{~mm}$

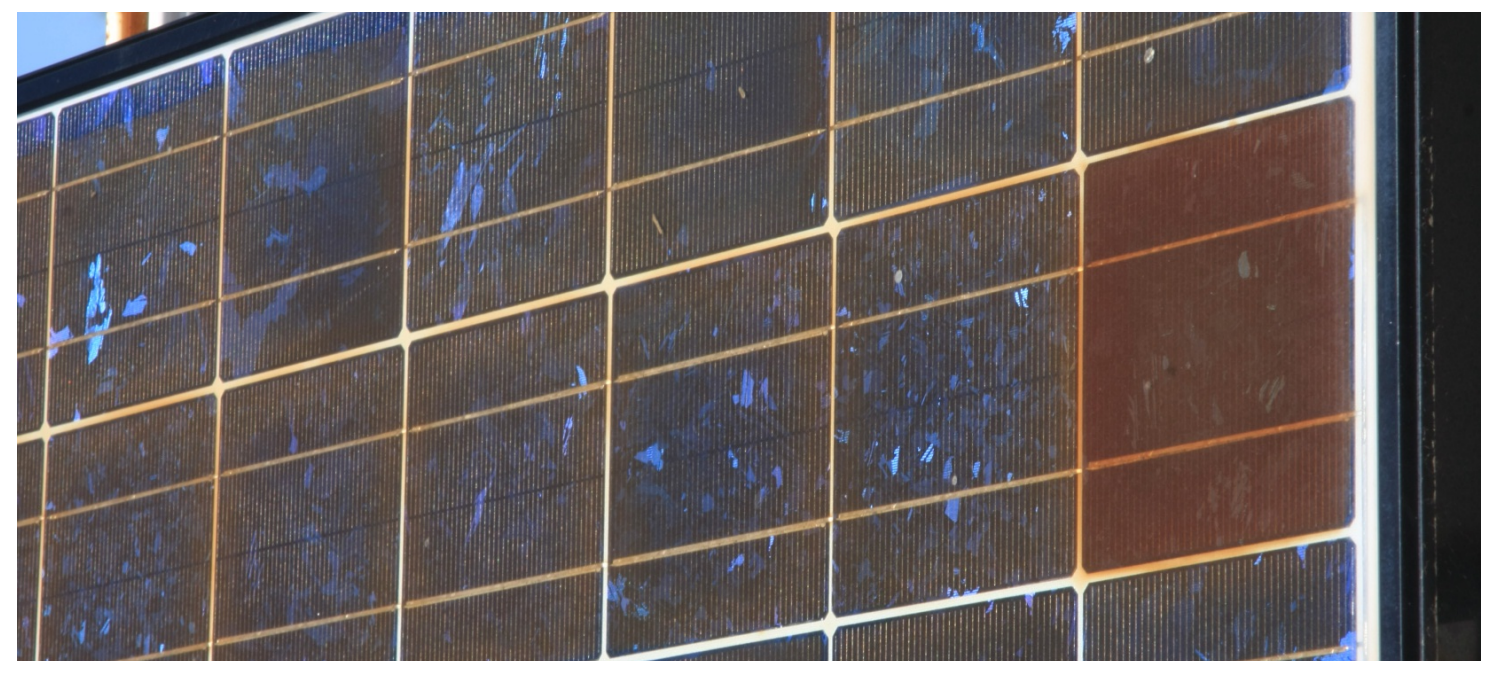




\section{Silicon Module: Discoloration}

Discoloration: $\square$ none/like new $\square$ light discoloration $\square$ dark discoloration

Number of cells with any discoloration:

of those, average \% discolored area:
ㄴ $<5 \%$
ㅁ $5-25 \%$
$\square 50 \%$
ㅁ $75 \%$
$100 \%$ (consistent overall)

Discoloration location(s) (mark all that apply):

$\square$ module center

$\square$ module edges

$\square$ cell centers

$\square$ over busbars

$\square$ over tabbing

$\square$ cell edges

$\square$ over gridlines

$\square$ partial cell discoloration

$\square$ individual cell(s)darker than others

more affected $\square$ less affected

Junction box area: $\quad \square$ same as elsewhere

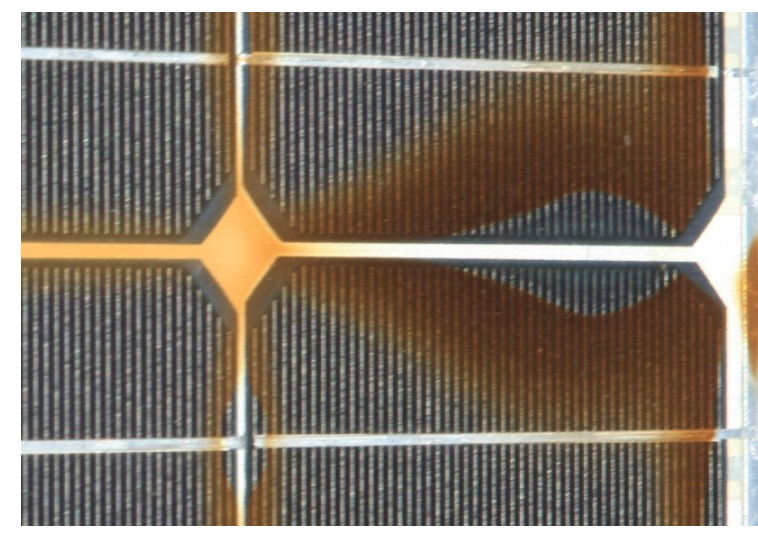

Dark discoloration at cell edges, between cells, and over gridlines and busbars

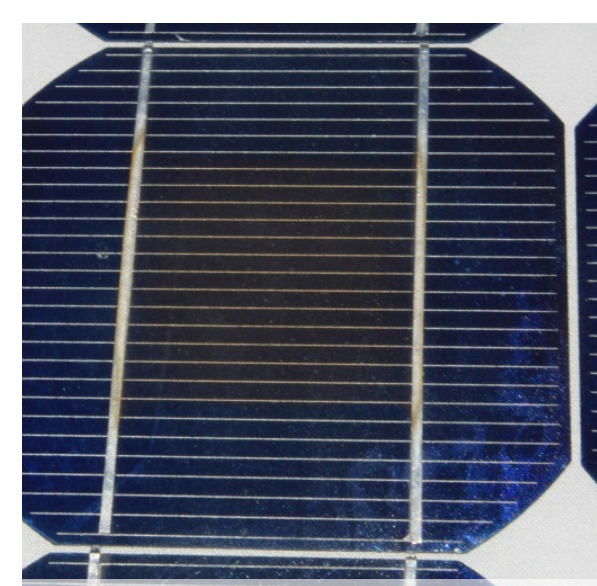

Light discoloration at cell center
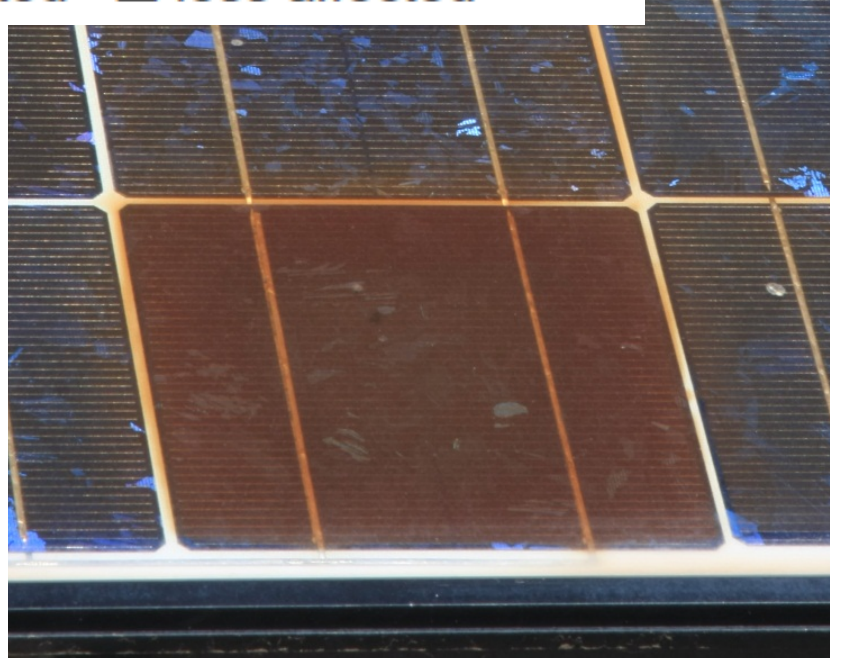

Light and dark discoloration with one individual cell darker than others 


\section{Silicon Module: Discoloration}

Discoloration: $\square$ none/like new $\square$ light discoloration $\square$ dark discoloration

Number of cells with any discoloration:

of those, average \% discolored area:
ㄴ $<5 \%$
ㅁ $5-25 \%$
$\square 50 \%$
ㅁ $75 \%$
$100 \%$ (consistent overall)

Discoloration location(s) (mark all that apply):
$\square$ module center
$\square$ module edges
$\square$ cell centers
$\square$ cell edges
$\square$ over gridlines
$\square$ over busbars
$\square$ over tabbing
$\square$ between cells
$\square$ individual cell(s)darker than others
$\square$ partial cell discoloration

Junction box area: $\quad \square$ same as elsewhere $\square$ more affected $\square$ less affected

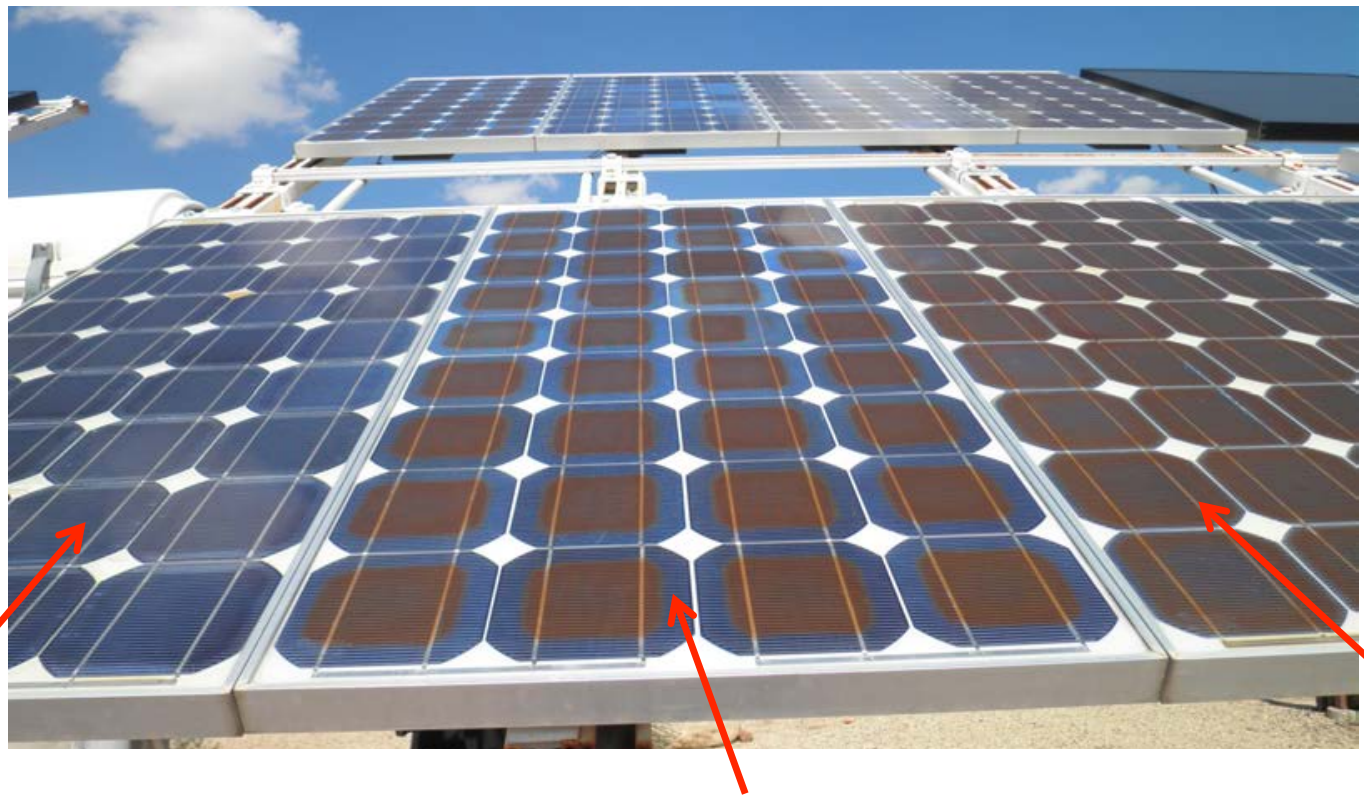

Discoloration over whole cell 


\section{Silicon Module: Damage}

\section{Damage: $\square$ none}

(mark all that apply): $\square$ burn mark (a.) $\square$ cracking (b.) $\square$ moisture

$\square$ worm marks/snail tracks (c.) $\square$ foreign particle embedded

(a.) Burns (\#): $\square 1 \quad \square 2 \quad \square 3 \quad \square$ 4-10 $\square>10$

(b.) Number of cells cracked:

(c.) Number of cells with worm marks/snail tracks:

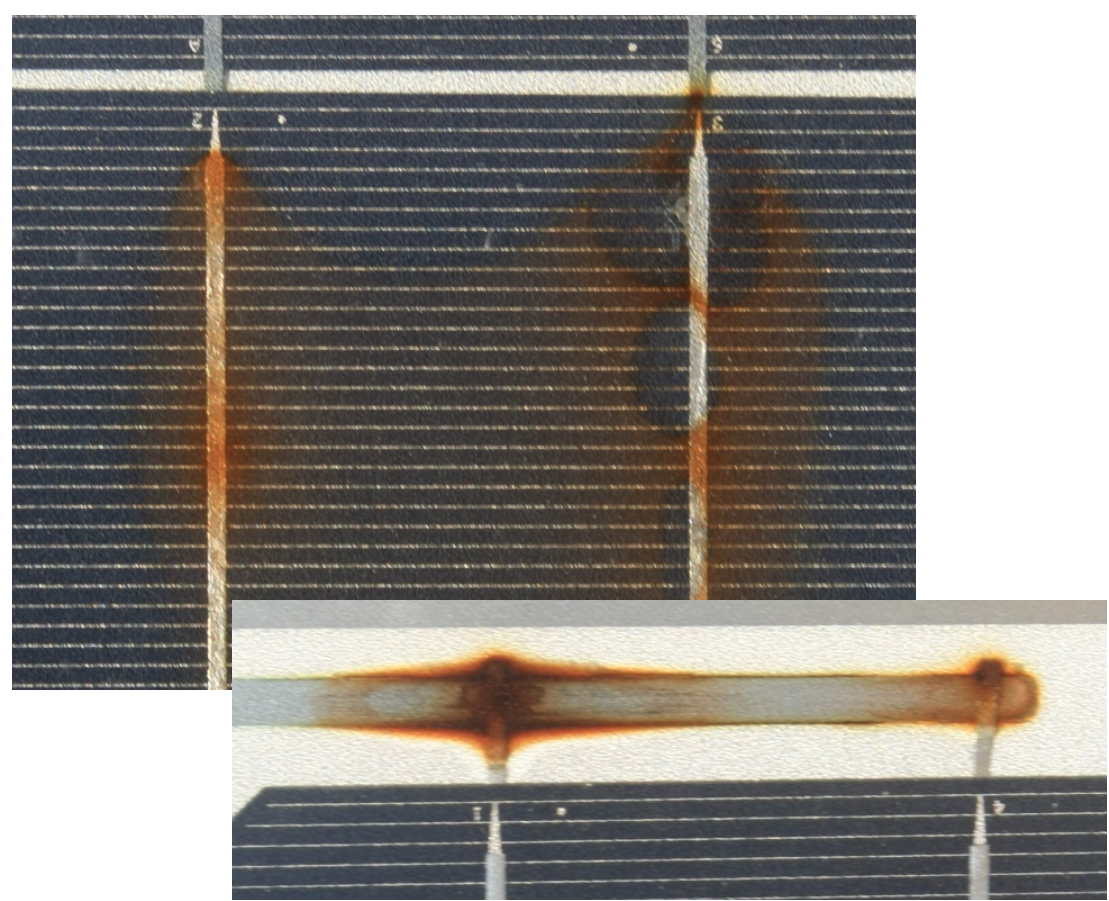

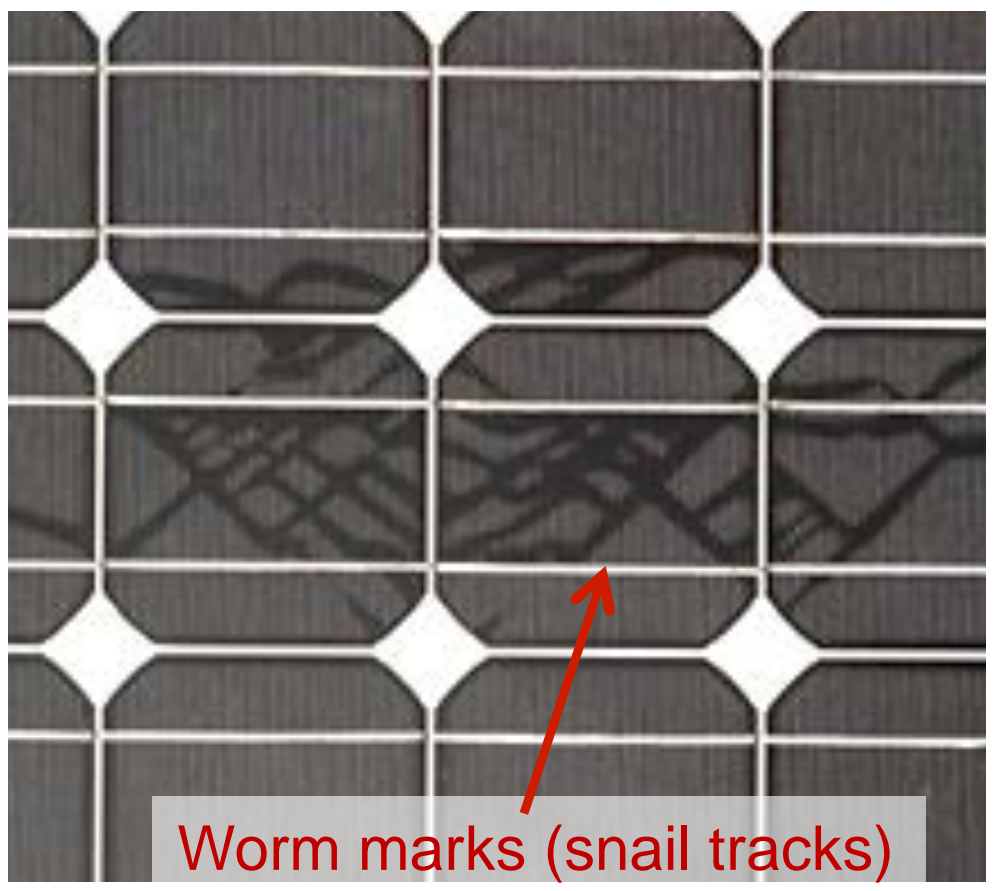

M. Kontges, K. Bothe, Elektrolumineszensmessung an Photovoltaik-Modulen Photovoltaik Aktuell supplement in Elektro Praktiker 7/ 2008, p. 36-40 


\section{Silicon Module: Delamination}

Delamination: $\square$ none $\square$ from edges $\square$ uniform $\square$ corner(s) $\quad \square$ near junction box $\square$ between cells (a.) $\square$ over cells (b.) $\square$ near cell or string interconnect

(a.) Fraction delamination between cells:

$\square<5 \% \quad \square 5-25 \% \quad \square 50 \% \quad \square 75-100 \%$ (consistent overall)

(b.) Fraction delamination over cells:
$\square<5 \%$
$\square-25 \%$
$\square 50 \%$
$\square \quad 75-100 \%$ (consistent overall)

Likely interface (choose 2):

$\square$ glass $\square$ semiconductor

(a)

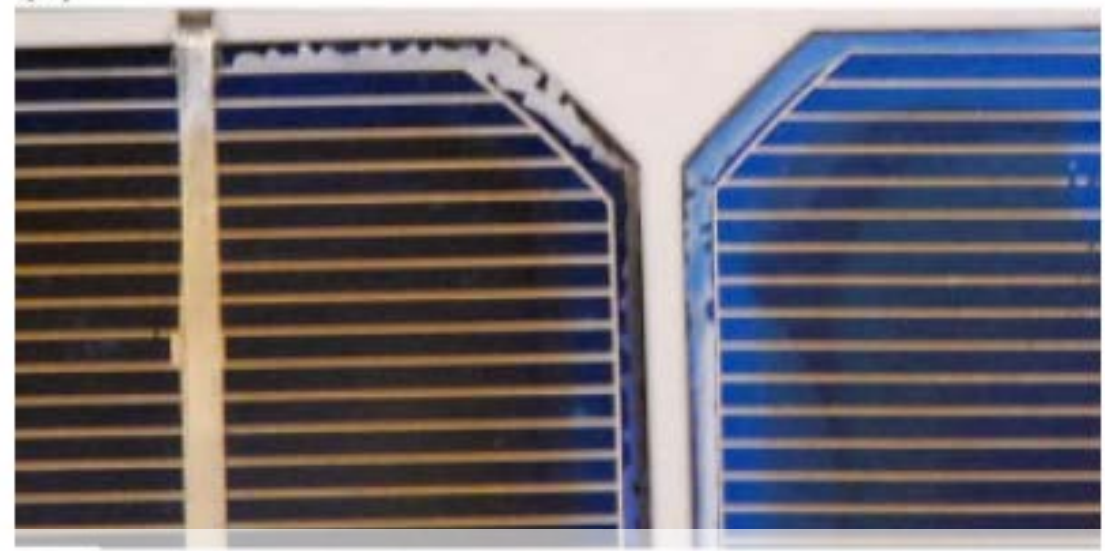

Semiconductor/Encapsulant delamination near edges

$\square$ encapsulant $\quad \square$ back sheet $\quad \square$ busbar

(b)
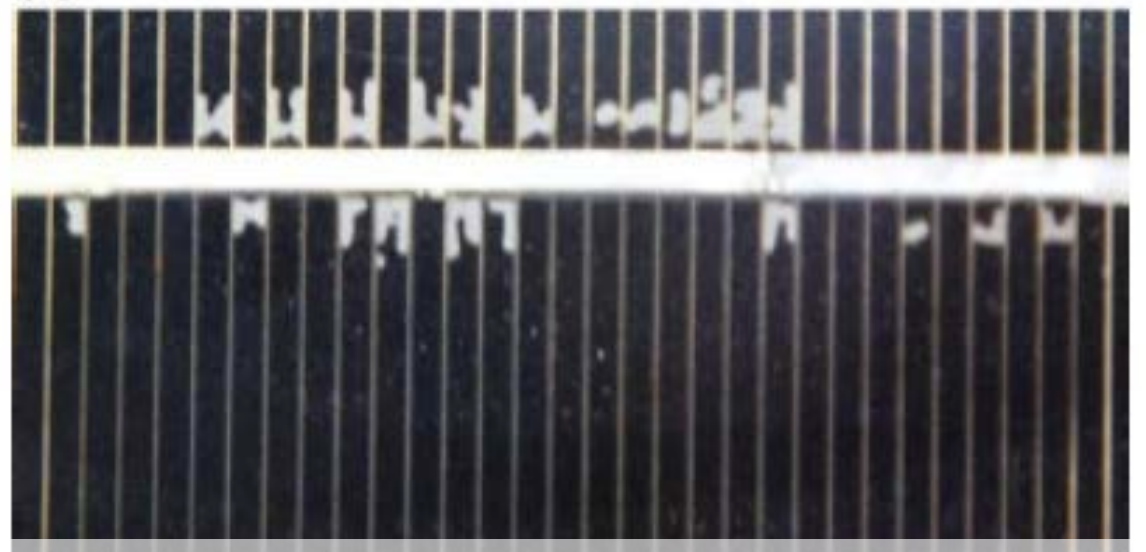

Semiconductor/Encapsulant delamination near busbar

Sanchez-Friera et al. Prog. Photovolt: Res. Appl. 2011 


\section{Thin Film Module}

\section{Thin film module: $\square$ not applicable $\square$ applicable}

Number of cells:

Number of cells in module

Number of cells in series/string

Number of strings in parallel

Cell size: Width $\mathrm{cm}$ Length

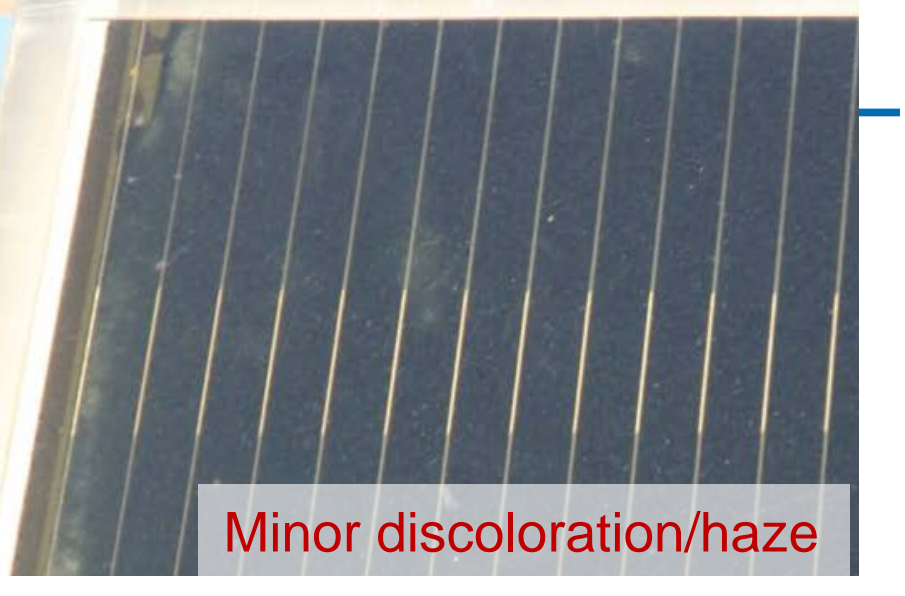

Distance between frame and cell: $\square>10 \mathrm{~mm} \quad \square<10 \mathrm{~mm}$ $\mathrm{cm}$

Appearance: $\square$ like new $\square$ minor/light discoloration $\square$ major/dark discoloration

Discoloration type (mark all that apply):

$\square$ spotted dearadation $\quad \square$ haze (encapsulant brownina) $\quad \square$ other

Discoloration location (mark all that apply):

$\square$ overall/no location pattern $\square$ module center

$\square$ module edge(s)

$\square$ cell center

$\square$ cell edges

$\square$ near $\operatorname{crack}(\mathbf{s})$

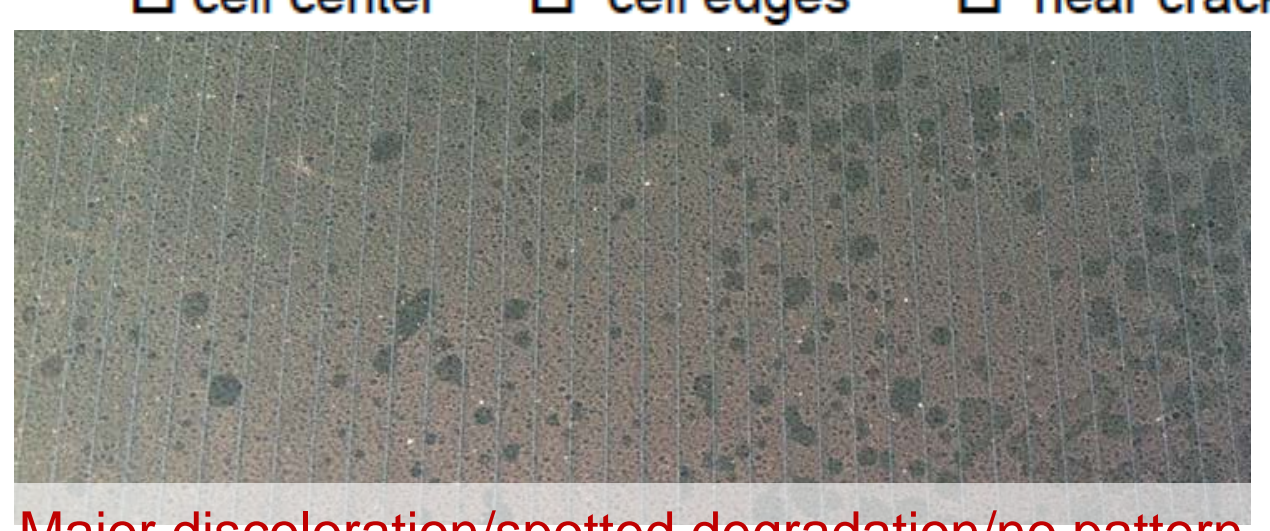

Major discoloration/spotted degradation/no pattern

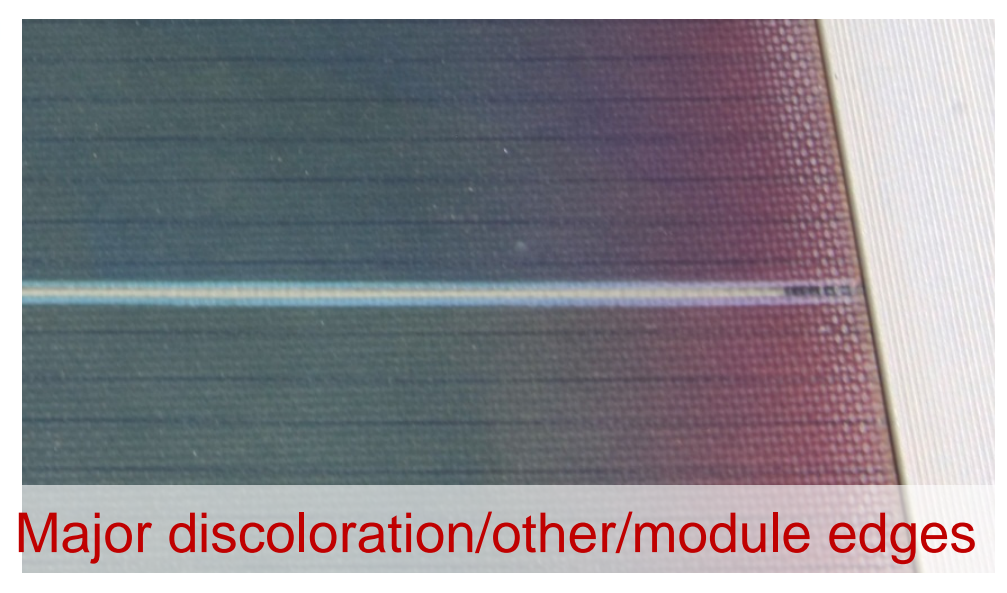




\section{Thin Film Module}

Damage: $\square$ no damage $\square$ small, localized $\square$ extensive

Damage Type (mark all that apply): $\square$ burn mark(s) $\square$ cracking

$\square$ possible moisture $\square$ foreign particle embedded

Foreign particle embedded

Delamination: $\square$ no delamination $\square$ small, localized $\square$ extensive

Location: $\square$ from edges $\square$ uniform $\square$ corner(s) $\square$ near junction box $\square$ near busbar $\square$ along scribe lines

Delamination Type: $\square$ absorber delamination $\square$ AR coating delamination $\square$ other

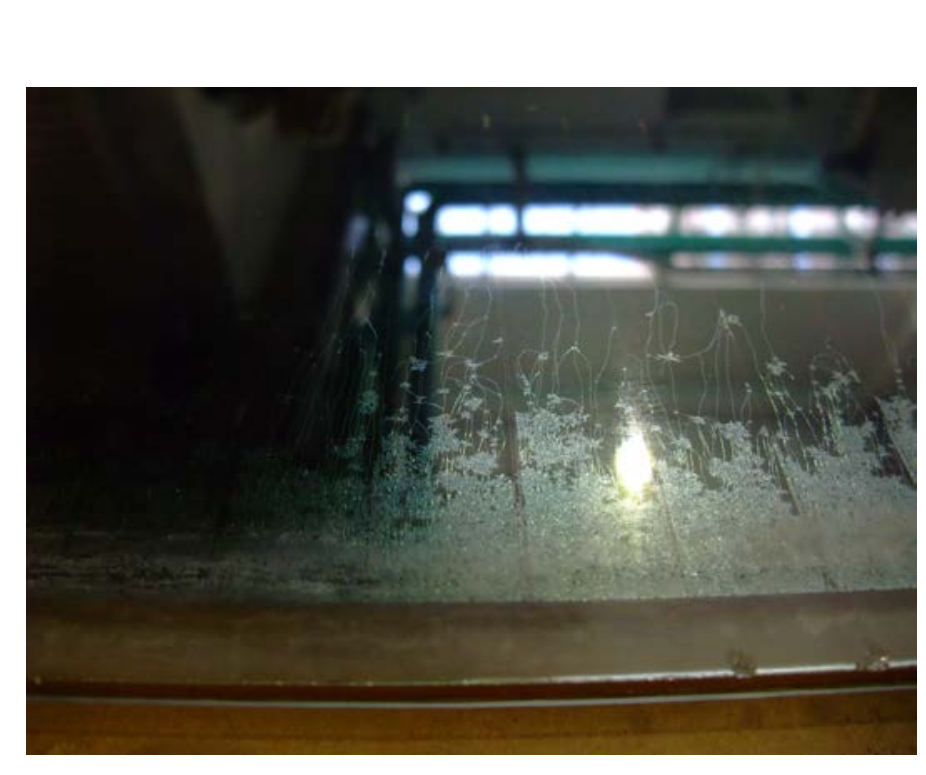

Absorber delamination

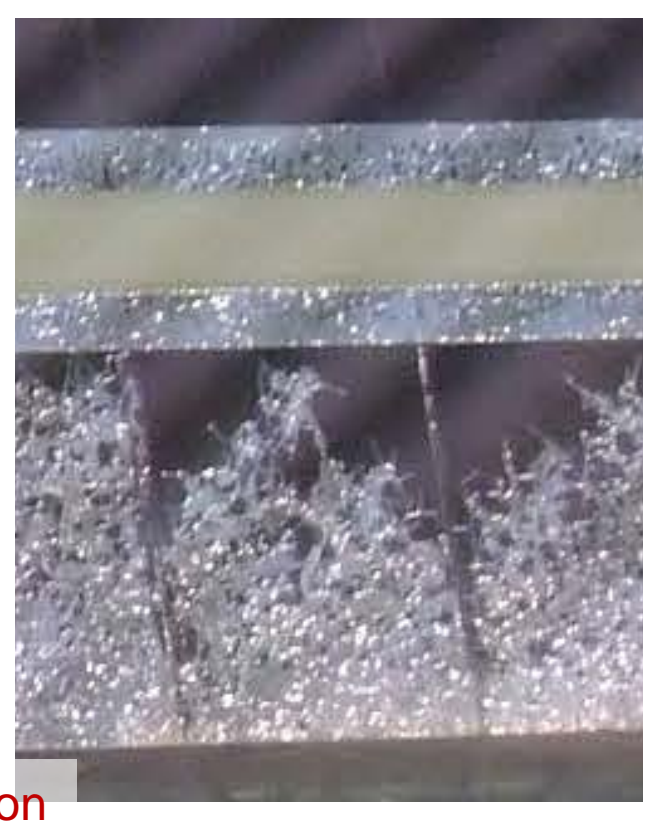

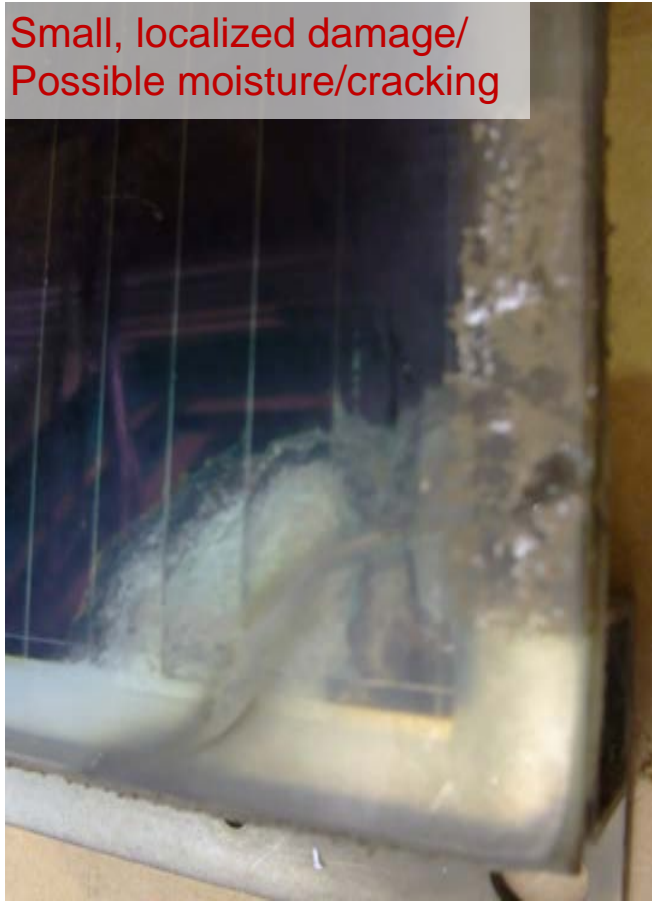

Small, localized damage/

Possible moisture/cracking 


\section{Electronic Records}

Photos taken of $\square$ front and defects

14. Electronic Records $\square$ applicable $\square$ not applicable

Photographs and I--V curves recorded electronically--list file names in blanks Photo files

I--V curve

Connector function: $\square$ functions $\square$ no longer mates $\square$ exposed Irradiance Sensor

Temperature Sensor

EL picture

IR picture

Bypass Diode Test: $\square$ applicable $\square$ not applicable

Number of diodes:

In total , shorted , open

OTHER 


\section{Documentation of module condition}

Date Name of data recorder

Location

\section{System Data}

System design: $\quad \square$ single module $\square$ multiple modules $\square$ unknown

\section{BEGIN INSPECTION AT BACK SIDE OF MODULE}

\section{Module Data}

$\begin{aligned} & \text { Technology: } \square \text { mono Si } \square \text { multi Si } \quad \square \text { a--Si } \square \text { CdTe } \quad \square \text { CIGS/CIS } \\ & \square \text { other: }\end{aligned}$
Estimated deployment date
Manufacturer
Model \#
Serial \#

\section{Rear-side Glass: $\square$ not applicable $\square$ applicable}

Damage: $\square$ no damage $\square$ small, localized $\square$ extensive

Damage Type (mark all that apply):

$\square$ crazing or other non--crack damage

$\square$ shattered (tempered ) $\square$ shattered (non-tempered ) $\square$ Cracked $\square$ Chipped

\section{Backsheet: $\square$ not applicable $\square$ applicable}

\begin{tabular}{cc} 
Appearance: $\square$ like new $\quad \square$ minor discoloration & $\square$ major discoloration \\
Texture: $\square$ like new $\square$ wavy (not delaminated) & $\square$ wavy (delaminated) $\quad \square$ dented \\
Material quality --chalking: $\square$ none $\quad \square$ slight & $\square$ substantial \\
Damage: $\square$ no damage $\quad \square$ small, localized & $\square$ extensive \\
Damage Type (mark all that apply): & \\
\hline burn marks $\quad \square$ bubbles $\quad \square$ delamination & $\square$ cracks/scratches
\end{tabular}

\section{Wires/Connectors:}

Wires: $\square$ not applicable $\square$ like new $\square$ pliable, but degraded $\square$ embrittled (mark all that apply): $\square$ cracked/disintegrated insulation $\square$ burnt $\square$ corroded $\square$ animal bites/marks

Connectors: $\square$ not applicable $\square$ like new $\square$ pliable, but degraded $\square$ embrittled Type: $\square$ unsure $\square$ MC3 or MC4 $\square$ Tyco Solarlok $\square$ other (mark all that apply): $\square$ cracked/disintegrated insulation $\square$ burnt $\square$ corroded 


\section{Junction Box:}

Junction box itself: $\square$ not applicable/observable $\square$ applicable Physical state: $\square$ intact $\square$ unsound structure (mark all that apply): $\square$ weathered $\square$ cracked $\square$ burnt $\square$ warped Lid: $\square$ intact/potted $\square$ loose $\square$ fell off $\square$ cracked

Junction box adhesive: $\square$ not applicable/observable $\square$ applicable Attachment: $\square$ well attached $\square$ loose/brittle $\square$ fell off Pliability: $\square$ like new $\square$ pliable, but degraded $\square$ embrittled

Junction box wire attachments: $\square$ not applicable/observable $\square$ applicable Attachment: $\square$ well attached $\square$ loose $\square$ fell off

Seal: $\square$ good seal $\square$ seal will leak

other: $\square$ arced/started a fire

\section{(7. Frame Grounding: Null)}

\section{CONTINUE INSPECTION ON FRONT SIDE OF MODULE}

\section{Frame: $\square$ not applicable $\square$ applicable}

Appearance: $\square$ like new $\quad \square$ damaged $\square$ missing

Frame Adhesive: $\square$ like new/not visible $\square$ degraded

\section{Frameless Edge Seal: $\square$ not applicable $\square$ applicable}

Appearance: $\square$ like new $\quad \square$ discoloration $\quad \square$ visibly degraded

Material problems:

$\square$ squeezed/pinched out $\quad \square$ shows signs of moisture penetration

Delamination: $\square$ none $\square$ area(s) delaminated

\section{Glass/Polymer (front):}

Material: $\square$ glass $\quad \square$ polymer $\quad \square$ glass/polymer composite $\quad \square$ unknown

Appearance: $\square$ clean $\square$ lightly soiled $\square$ heavily soiled

Damage: $\square$ no damage $\square$ small, localized $\square$ extensive

Damage Type (mark all that apply):

$\square$ crazing or other non--crack damage $\square$ shattered (tempered)

$\square$ shattered (non--tempered) $\square$ Cracked $\square$ Chipped $\square$ milky discoloration

\section{Metallization:}

Appearance: $\square$ like new $\square$ light discoloration $\quad \square$ dark discoloration 


\section{Silicon (mono or multi) module: $\square$ not applicable $\square$ applicable}

Discoloration: $\quad \square$ none/like new $\quad \square$ light discoloration $\quad \square$ dark discoloration

Damage: $\square$ none

(mark all that apply): $\square$ burn mark(s) $\square$ cracking $\square$ moisture

$\square$ worm marks/snail tracks $\square$ foreign particle embedded

Delamination: $\square$ none $\square$ from edges $\square$ uniform $\square$ corner(s) $\quad \square$ near junction box

$\square$ between cells $\square$ over cells $\square$ near cell or string interconnect

\section{Thin film module: $\square$ not applicable $\square$ applicable}

Appearance: $\square$ like new $\square$ minor/light discoloration $\square$ major/dark discoloration

Damage: $\quad \square$ no damage $\square$ small, localized $\square$ extensive

Damage Type (mark all that apply): $\square$ burn mark(s) $\square$ cracking

$\square$ possible moisture $\square$ foreign particle embedded

Delamination: $\square$ no delamination $\square$ small, localized $\square$ extensive

Location: $\square$ from edges $\square$ uniform $\square$ corner(s) $\square$ near junction box $\square$ near busbar $\square$ along scribe lines 